\section{Otizm Spektrum Bozukluğuna Sahip Çocukları Olan Annelerinin Okulöncesi Eğitim Hizmetleri Sürecine İlişkin Deneyimlerinin İncelenmesi}

\author{
Examining Experience of Mothers of \\ Children with Autism about Preschool \\ Services
}

Turkish Journal of Special Education

Research and Practice

2021, Volume 3, Number 1, p 23-46 https://dergipark.org.tr/trsped

DOI: 10.37233/TRSPED.2021.0111

Article History:

Received 11 January 2021

Revised 22 June 2021

Accepted 23 June 2021

Available online 15 December 2021

\begin{abstract}
Safiye Ateş (i)1, Salih Rakap (iD) 23
Öz

Otizm spektrum bozukluğu (OSB) olan çocukların erken tanılanması, bu çocukların özel eğitim hizmetlerine erken bir zamanda erişmelerine, gelişimsel dönem içerisinde bu hizmetlerden uzun süre ve yoğunlukta yararlanmalarına firsat vermektedir. Bu bağlamda ailelerin tanılama ve okulöncesi eğitim süreçlerinde yaşadıkları deneyimlerin belirlenmesi, çocukların bu süreçlerde etkili hizmet alabilmeleri açısından önemlidir. Bu araştırmada, OSB'den etkilenmiş çocukların annelerinin çocuklarının tanı alma ve okulöncesi eğitim hizmetleri sürecine ilişskin deneyimlerinin incelenmesi amaçlanmıştır. Araştırmaya, çocukları OSB tanısı almış olan 14 anne katılmıştır. Araştırmada nitel araştırma desenlerinden durum çalışması kullanılmış; veriler yarı yapılandırılmış görüşmeler yoluyla toplanmış ve içerik analiz kullanılarak analiz edilmiştir. Bulgular, annelerin tanı alma sürecine kendi şüpheleri, bir yakınlarının ya da çocuklarının öğretmenlerinin yönlendirmesiyle girdiklerini ve bu sürecin genellikle 2-4 yaş aralı̆̆ında tamamlandığını; çalışmaya katılan tüm çocukların tanı alma süreci sonrası özel eğitim ve rehabilitasyon hizmetlerinden yararlanmaya başladıklarını ancak bu hizmetlerin kalitesinin yeterli olmadığını, dahası OSB'den etkilenmiş bu çocukların okulöncesi eğitime erişimde birçok güçlükle karşılaştığını ortaya koymuştur. Çalışmanın bulguları ve sonuçları doğrultusunda ileriki araştırma ve uygulamalar için önerilerde bulunulmuştur.
\end{abstract}

Anahtar Sözcükler: Otizm spektrum bozukluğu, anne, tanılama, okul öncesi eğitim, rehabilitasyon.

\begin{abstract}
Early diagnosis that allows children with autism to have access to special and preschool education services as early as possible is critical in the treatment of autism. Determining the experiences of mothers of children with autism in the process of diagnosis and preschool education can support children's access to improved services. The purpose of this study was to investigate experiences of mothers of children with autism during diagnosis and early education process. A qualitative research method was used. Fourteen mothers of children with autism participated in this study. Data were collected through semi-structured interviews and analyzed using descriptive and content analysis. Findings revealed that mothers started diagnosis process due to their own doubts, with the guidance of their relatives or their children's teachers and that diagnosis process was generally completed in 2-4-year range. Findings also revealed all children started to receive special education and rehabilitation services after diagnosis, but the quality of these services varied. Moreover, children with autism faced many challenges in accessing preschool education. Suggestions for future research and practice are provided based on the findings and results of the study.
\end{abstract}

Keywords: Autism spectrum disorder, mother, diagnosis, preschool education, rehabilitation.

Önerilen Atıf Şekli (Suggested Citation): Ateș, S., \& Rakap, S. (2021). Otizm spektrum bozukluğuna sahip çocukları olan annelerinin okulöncesi eğitim hizmetleri sürecine iliş̧kin deneyimlerinin incelenmesi. Turkish Journal of Special Education Research and Practice, 3 (1), 23-46. https://doi.org/10.37233/TRSPED.2021.0111

\footnotetext{
${ }^{1}$ Evin Özel Eğitim Danışmanlık Merkezi, İstanbul, Türkiye, e-posta: evinozelegitim@gmail.com, ORCID: https://orcid.org/0000-0003$\underline{0138-0335}$

2 Ondokuz Mayıs Üniversitesi, Eğitim Fakültesi, Özel Eğitim Bölümü, Samsun, Türkiye, e-posta: s_rakap@uncg.edu, ORCID: https://orcid.org/0000-0001-7853-3825

${ }^{3}$ University of North Carolina Greensboro, Department of Specialized Education Services, NC, USA, e-posta: s_rakap@uncg.edu, ORCID: https://orcid.org/0000-0001-7853-3825
} 


\section{Giriş}

Otizm spektrum bozukluğu (OSB) bireylerin sosyal etkileşim ve iletişim kurma becerilerini olumsuz yönde etkileyen, sınırlı ilgi ve tekrarlanan davranışlara neden olan nörogelişimsel bir bozukluktur (Leblanc vd., 2009). OSB'nin belirtileri yaşamın erken dönemlerinden itibaren görülmeye başlanmakla birlikte, etiyolojisi hakkında halen sınırlı düzeyde bilgi ve bulgu bulunmaktadır (Rakap, 2017). Yapılan araştırmalar, genetik ve çevresel faktörlere ek olarak beyin gelişimi sırasında, beynin yapısında ya da işlevinde ortaya çıkan anormalliklerin OSB'ye neden olduğu ile ilgili güçlü bulgular ortaya koymaktadır. Nörogelişimsel bozukluklar arasında zihin yetersizliğinden sonra ikinci sırada yer alan OSB'nin görülme sıklığı her geçen yıl artmaktadır (Rakap, 2017). Amerika Birleşik Devletleri Hastalıkları Kontrol ve Önleme Merkezi (Centers for Disease Control and Prevention, CDC) verilerine göre 2000 yılında her 150 çocuktan birinde OSB görülürken, 2016 yılında bu oran 54 çocukta bire yükselmiştir (CDC, 2020).

OSB'nin nedenleri ile ilgili kesinleşmiş araștırma bulguları olmamakla birlikte, otuz yılı aşkın süredir yürütülen araştırmalar OSB'nin tedavisinde en etkin sonuçların, çocuğun erken dönemde tanılanması ve en kısa sürede özel eğitime ve yoğun davranışsal terapiye başlamasıyla elde edildiğini göstermektedir (Reichow vd., 2012; Volkmar vd., 2014). Ancak, Amerika Birleşik Devletleri (ABD) gibi yıllardır OSB alanında çalışmaların yapıldığı ve bu alanda en etkili müdahale programlarının geliştirildiği ülkelerde dahi OSB'li küçük çocukların ve ailelerinin tanılama, değerlendirme ve erken eğitime erişimi konularında sınırlılıklar yaşandığı görülmektedir (Rakap, 2017). Bu sınırlılıklarla başa çıkmak için atılması gereken adımlardan biri OSB tanısı almış çocukların ebeveynlerinin değerlendirme, tanılama ve erken eğitim süreçlerinde yaşadıkları deneyimlerin incelenmesi yoluyla karşılaşılan problemlerin ve çözüm yollarının belirlenmesidir.

Erken müdahalenin OSB'li çocuklar üzerindeki etkileri ve yararları göz önünde bulundurulduğunda, bu özel gereksinime sahip olan çocukların kapsamlı bir değerlendirme süreci kullanılarak tanılanmaları ve eğitim süreçlerinin zamanında doğru bir şekilde planlanması oldukça önemlidir (Reichow vd., 2012; Rakap, 2017). Ancak, ülkemizde OSB'li çocuklarla ya da yetişkinlerle çalışmak üzere eğitim almış, nitelikli personel sayısı yok denecek kadar azdır (Rakap, 2017). Uzman personel sayısındaki yetersizlik, OSB'li çocukların kapsamlı bir şekilde değerlendirilmesi, tanı alması, kaliteli erken müdahale ve okulöncesi hizmetlerinden yararlanması konularında önemli sınırlılıklar oluşturmaktadır (Rakap, 2017). Bu bağlamda, OSB'nin ilk belirtilerinin fark edilmesinden tanılamaya ve tanı alındıktan sonra erken eğitim ve okulöncesi eğitim programlarına erişime kadar geçen sürede OSB'li çocukların ve ailelerinin karşılaşmış olduğu birçok problem bulunmaktadır.

Ulusal alanyazında, OSB'den etkilenmiş çocukları olan aileler ile yapılmış ve aileler ile ilgili farklı değişkenleri inceleyen birkaç çalışma bulunmaktadır (Bıçak, 2009; GüleçAslan vd., 2014; Selimoğlu vd., 2013; Töret vd., 2015; Ünsal ve Öksüz, 2009; Üstüner-Top, 2009). Örneğin, Bıçak (2009), OSB tanılı çocukların annelerinin yaşadıkları duygu durumlarını incelediği çalışmada OSB'den etkilenmiş çocukları olan annelerin, çocuklarında OSB olduğunu öğrendikten sonra yoğun duygular yaşadıklarını, aile içi ve sosyal ilişkilerinin olumsuz olarak etkilenerek değiştiğini ve çocuklarının gelecekleri ile ilgili endișe yaşadıklarını belirlemiştir. Araştırma bulguları ayrıca annelerin yoğun bir şekilde şok, kızgınlık, pişmanlık, depresyon ve inkâr gibi duygular yaşadıklarını ve otizm ile ilgili bilgi kaynağı olarak eğitimcileri, doktorları, internet kaynaklarını ve özel eğitim merkezlerini kullandıklarını göstermiştir. Başka bir çalışmada, Ünsal ve Öksüz (2009), uzmanların ve ebeveynlerin OSB olan çocukların kaynaştırılması ile ilgili görüşlerini incelemişlerdir. Bu çalışmanın bulguları, kaynaştırma eğitimi uygulamaları ve çocuklara 
sağladıkları yararlar bağlamında bireysel farklılıklar olduğunu, kaynaştırma eğitimi uygulamaları konusunda olumlu ve olumsuz öğretmen tutumlarının, çocuklara katkıyı önemli düzeyde etkilediğini, okul personelinin özel gereksinimli çocukların eğitimleri ve kaynaştırma uygulamaları ile ilgili eksik bilgiye sahip olduklarını göstermiştir.

Üstüner-Top (2009), OSB'ye sahip çocuğu olan ailelerin yaşadıkları sorunlar ile ruhsal durumlarını incelediği çalışmada, ailelerin çocuklarına OSB teșhisi konulduğunda kabullenmekte zorlandıklarını, çocuklarına tanı konulmasından itibaren yaşam tarzlarının değiştiğini, çevreden soyutlandıklarını ve daha hassas ve duygusal olduklarını ve çocuklarının eğitim ve gelecekleri ile ilgili kaygı yaşadıklarını belirlemiştir. Güleç-Aslan vd. (2014) ise OSB tanılı çocuk sahibi annelerin deneyimlerini inceledikleri çalışmalarında, annelerin pek çoğunun OSB'yi hayatlarını olumsuz etkileyen bir durum olarak algıladıklarını ve bunun temel nedenlerinin ise OSB'nin kesin bir tedavisi olmayıp yaşam boyu süren bir durum olması, eğitimle ilişkili yaşadıkları sorunlar, çocuklarının gelecekteki durumlarının belirsizliği, OSB ile yaşamanın özellikle annelere getirdiği sorumluluklar ve sosyal yaşamdaki kısıtlamalar olduğunu rapor etmiştir.

Selimoğlu vd. (2013), OSB tanılı çocukların ebeveynlerinin OSB'nin tanımı ve nedenlerine ilişkin görüşlerini inceledikleri çalışmada, ebeveynlerin OSB'nin tanımı ve nedenleri konusunda sınırlı düzeyde bilgi sahibi olduklarını, çocuklarında gözlemledikleri dil, konuşma ve iletişim bozukluklarının OSB tanısı ile uyumlu olduğunu düşündüklerini ve çocuklarının OSB tanısı ile ilişkili olmayan bir şekilde öğrenme veya davranış özellikleri sergilediklerini belirttiklerini rapor etmiştir. Töret vd. (2015) ise ağır düzeyde OSB olan çocuklar ile annelerinin, ebeveyn-çocuk etkileşimlerini incelemişler ve ağır düzeyde OSB olan çocuk annelerinin çocuklarına yönelik etkileşimlerinde yüksek düzeyde yönlendirici etkileşim stiline sahip olduklarını, duygusal ifade edici olma ve yanıtlayıcı etkileşim stiline sahip olma düzeylerinin ise düşük olduğu bulmuşlardır. Ayrıca, ağır düzeyde OSB olan çocukların anneleri ile olan etkileşimlerinde, düşük düzeyde dikkat ve başlatma etkileşim stiline sahip oldukları görülmüştür. OSB'li çocukların ebeveynleri ile yapılan çalışmalara bakıldığında, ebeveynlerin tanılama ve okulöncesi eğitim hizmetleri sürecine ilişkin deneyimlerinin incelendiği çalışmaların çok sınırlı düzeyde olduğu görülmektedir. Bu nedenle, bu çalışmada, okulöncesi yaş grubunda yer alan OSB tanısı almış çocukları olan annelerin tanılama ve okulöncesi eğitimi sürecine ilişkin deneyimleri incelenmiştir.

$\mathrm{Bu}$ çalışmanın amacı, OSB'den etkilenmiş çocukların annelerinin, tanı alma ve bu çocukların gelişim ve öğrenmelerinde önemli bir role sahip olan okulöncesi eğitim hizmetleri sürecine ilişkin deneyimlerinin incelenmesidir. $\mathrm{Bu}$ amaç doğrultusunda yapılan bu çalışmada aşağıdaki araştırma sorularına yanıt aranmıştır:

1. OSB'den etkilenmiş çocuğu olan annelerin çocuklarının tanı alma sürecine ilişkin deneyimleri nelerdir?

2. OSB'den etkilenmiş çocuğu olan annelerin çocuklarını okulöncesi eğitim kurumlarına kaydettirirken yaşadıkları deneyimler nelerdir?

3. OSB'den etkilenmiş çocuğu olan annelerin çocuklarının okulöncesi eğitimi sırasında yaşadıkları deneyimler nelerdir?

4. OSB'den etkilenmiş çocuğu olan annelerin okulöncesi eğitim kurumlarında görev yapan yöneticiler ve öğretmenler ile bu kurumlarda eğitim alan normal gelişim gösteren çocuklar ve aileleri ile yaşadıkları deneyimler nelerdir?

5. OSB'den etkilenmiş çocuğu olan annelerin çocuklarının okulöncesi dönemde aldıkları eğitim hizmetlerinin kalitesi ile ilgili görüşleri nelerdir?

$\mathrm{Bu}$ çalışmadan elde edilen bilgi ve bulguların, OSB'li çocukların tanılanma ve okulöncesi eğitimi süreçlerinin niteliğinin artırılmasına katkıda bulunacağı 
düşünülmektedir. Ayrıca, bu çalışma, ebeveynlerin çocuklarını daha ayrıntılı değerlendirmeleri ve OSB'den etkilenmiş çocukların erken dönemde uygun yoğunlukta ve nitelikli eğitim almaları hususunda farkındalık oluşturmaya katkı sağlayacaktır. Ek olarak, çalışma kapsamında elde edilen bulguların, okulöncesi eğitim kurumlarında görev yapan yönetici ve öğretmenler ile bu okullarda öğrenim gören normal gelişim gösteren çocuklar ve ailelerinin OSB'li çocuklar ve bu çocukların eğitimleri konusunda farkındalıklarının artırılmasına yönelik çalışmalara yol gösterecektir. Son olarak, bu çalışmanın bulguları, Millî Eğitim Bakanlığı'nın okul öncesi eğitimi her çocuk için erişilebilir hale getirme ve nitelikli eğitim sunma çalışmaları ile bu bağlamda geliştirilecek politikalara katkı sağlayacaktır.

\section{Yöntem}

\section{Araştırma Modeli}

Bu çalışmada, OSB'li çocukları olan annelerin çocuklarına tanı konulması ve çocuklarının okulöncesi eğitimi sürecinde yaşadıkları deneyimler ile ilgili görüşlerini derinlemesine incelemek ve durumlarını ayrıntılı bir şekilde değerlendirmek amacıyla nitel araștırma desenlerinden durum çalışması kullanılmıştır. Durum çalışması, özel bir olayın farklı bakış açıları kullanılarak incelenmesi olup; bir olayı meydana getiren ayrıntıları tanımlamak ve görmek; bir olaya ilişskin olası açıklamaları geliştirmek ve bir olayı derinlemesine değerlendirmek amacıyla kullanılır (Creswell, 1998).

\section{Katılımcılar (Çalışma Grubu)}

Bu çalışmaya, İstanbul ili, Sancaktepe ve Ümraniye ilçelerinde yaşayan ve çocukları OSB tanısı almış olan 14 anne katılmıştır. Katılımcılar, seçkisiz olmayan bir örnekleme yaklaşımı olan amaçlı örnekleme yöntemlerinden ölçüt örneklemeye göre belirlenmiştir. Ölçüt örnekleme metodu kullanılan araştırmalarda gözlem birimleri belli niteliklere sahip kişiler, olaylar, nesneler ya da durumlardan oluşur (Büyüköztürk vd., 2015). Buna göre araştırmaya katılacak annelerin seçiminde üç ölçüt kullanılmıştır: (1) çocuklarının OSB tanısı almış olması, (2) çocuklarının 4-7 yaş aralığında olması ve (3) çalışmaya katılmaya gönüllü olması. Tablo 1'de araştırmaya katılan annelerin demografik özellikleri sunulmuştur.

Tablo 1. Çalıșmaya katılan annelere ilişkin demografik bilgiler $(n=14)$

\begin{tabular}{lcc}
\hline Demografik Özellikler & $\mathrm{F}$ & $\%$ \\
\hline Yaş & & \\
31-33 & 3 & 21.4 \\
36-39 & 9 & 64.3 \\
$\quad$ 40ve üzeri & 2 & 14.3 \\
Ĕgitim & 4 & \\
$\quad$ Illkokul & 7 & 28.6 \\
$\quad$ Ortaokul/lise & 3 & 49.9 \\
$\quad$ Ön lisans/Lisans & & 21.4 \\
Meslek & 11 & 78.5 \\
$\quad$ Ev hanımı & 3 & 21.5 \\
Öğretmen/muhasebeci/terzi & 14 & 100 \\
Medeni hal- evli & & \\
Ekonomik durum & 3 & 21.4 \\
1500-2000 & 5 & 35.7 \\
2000-2500 & 2 & 14.3 \\
2500-3000 & 4 & 28.6 \\
3000 ve üzeri & & \\
\hline
\end{tabular}




\section{Veri Toplama Araçları}

Demografik Bilgi Formu. Araştırmaya katılan anneler, çocukları ve aileleri hakkında genel bilgiler elde etmek amacıyla araştırmacılar tarafından geliştirilmiştir. Formda, araştırmaya katılan annelerin yaşları, eğitim durumları, meslekleri ve medeni halleri ile ilgili sorulara ek olarak eşlerinin mesleki durumları ve çocuk sayılarına ilişkin birer soru yer almaktadır. Form, sözel olarak görüșme oturumlarının başında araştırmacı tarafından katılımcı annelere sorularak tamamlanmıştır.

Görüşme Formu. Araştırmaya katılan OSB tanısı almış çocukları olan annelerden yarı yapılandırılmış görüşmeler yoluyla veri toplamak amacıyla araştırmacılar tarafından geliştirilmiştir. Formda, OSB tanısı almış çocukları olan annelerin tanı alma ve okulöncesi eğitim döneminde yaşadıkları deneyimleri belirlemek amacı ile beş açık uçlu soruya yer verilmiştir. Formda yer alan sorular çalışma grubuna uygulanmadan önce iki özel eğitim uzmanından görüş alınmış ve çalışmaya katılmayan bir OSB'li çocuk annesine uygulanmıştır. Uzmanların ve ebeveynin önerileri doğrultusunda düzenlemeler yapılarak forma son hali verilmiştir.

\section{Veri Toplama İşlemleri}

Çalışma bağlamında veri toplama işlemleri (görüşmeler) annelerin çocuklarının eğitim aldıkları okulöncesi ya da özel eğitim ve rehabilitasyon merkezlerine geldikleri saatlerde, anneler ile daha önceden belirlenen günlerde psikolog odasında gerçekleştirilmiştir. Görüşmelerin tamamı birinci araştırmacı tarafından katılımcılar ile bireysel olarak gerçekleştirilmiş ve katılımcı annelerden izin alınarak tüm görüşmeler ses kayıt cihazı ile kaydedilmiştir. Anne ile yapılan görüşmeler 32-40 dakika (ortalama = 36 dakika) sürmüştür. Her görüşmenin başında, katılımcılara çalışmanın amacı ve elde edilen bilgilerin gizlilik ilkeleri ve katılımcı olarak hakları doğrultusunda nasıl kullanılacağı tekrar açıklanmış ve gönüllü katılım formları imzalatılmıştır. Görüşmeler sırasında, katılımcılara görüşme formunda yer alan sorular aynı sıra ile sorulmuş; soruları cevaplamada tereddüt yaşadıkları ya da daha fazla bilgiye ihtiyaç duydukları durumlarda ebeveynlere ek bilgiler sağlanmış ve sağlanan ek bilgiler not edilmiştir. Görüşmeler sırasında her bir soru için katılımcı annelerden kapsamlı ve doyurucu cevaplar alındıktan sonra bir sonraki soruya geçilmiş, sorular sorulurken ve ek bilgilendirme yapılırken katılımcıları yönlendirici tepkilerden kaçınılmıştır. Katılımcıların sorulan sorulara konu dışında yanıt vermeleri durumunda herhangi bir müdahalede bulunulmamış, annenin konuşması bittikten sonra soru tekrar edilerek yönlendirme yapılmıştır. Çalışmaya ilişkin etik kurul onayı Okan Üniversitesi Etik Kurulu'ndan (04.07.2018 tarih ve 29 sayı) alınmıştır.

\section{Veri Analizi}

Çalışmada toplanan nitel verilerin analizi için betimsel ve içerik analizi yöntemleri kullanılmıştır. Elde edilen veriler bu yaklaşımlara göre çözümlenerek yorumlanmıştır. Betimsel analizde, görüşülen bireylerin görüşlerini dikkat çekici bir biçimde yansıtmak amacı ile doğrudan alıntılara yer verilir (Büyüköztürk vd., 2015). İçerik analizi, belirli kurallara dayalı kodlamalarla bir metnin bazı kelimelerinin daha küçük içerik kategorileri ile özetlendiği sistematik, yinelenebilir bir teknik olarak tanımlanır (Büyüköztürk vd., 2015). Veri analizleri bağlamında ilk olarak görüşme esnasında tutulan ses kayıtları hiçbir değişiklik yapılmadan görüşmelerin yapılış sırasına göre sıra numarası verilerek kâğıda aktarılmıștır. Veriler kâğıda aktarılırken katılımcılar 'K1, K2..., K13, K14' șeklinde kodlanmıştır. Ses kayıtlarının yazıya dökümü sırasında katılımcıların ve araştırmacının 
yaptıkları tüm konuşmalar duyulduğu şekliyle hiçbir değişiklik yapılmadan sırasıyla kaydedilmiştir. Veri analizi aşamasına geçilmeden önce güvenilirlik amacıyla görüşme ses kayıtlarından rastgele seçilen 4'ü, ikinci bir gözlemci tarafından dinlenerek yazılı dökümlerin doğruluğu kontrol edilmiştir. Bu bağlamda, gözlemciler arası güvenilirlik \%100 olarak hesaplanmıştır.

Kâğıda aktarılan veriler özetlenerek, temalara ve alt kategorilere ayrılmıştır. Var olan bilgiler azaltma ve ortak bir fikir oluşturma amaçlı organize edilip kodlanarak temalara ayrılmıştır. Araştırmacı, temaları oluşturma işleminde kodlama dosyalarındaki verileri okuyarak aynı tema altında toplayabileceği verilere birer başlık vermiş ve bu başlıklara uygun aile konuşmalarını organize ederek verileri düzenlemiştir. Bu düzenlemeden sonra elde edilen başlıklar araştırmanın temalarını, alt başlıklar ise alt temalarını oluşturmuştur. Araştırmacı tarafından oluşturulan temalar kodlamalarla beraber özel eğitim alanında çalışmalar yapan (ikincil kodlayıcı) bir araştırmacı tarafından gözden geçirilmiştir. Araştırmacı ve ikincil kodlayıcı tarafından görüş birliğine varılan temalar aynen bırakılmış, görüş ayrılığında olunan temalar üzerinde tartışılmıştır. Uzlaşmaya varıldıktan sonra tüm temalar ve alt temalar yeniden düzenlenmiștir. Kodlamalar sırasında, katılımcıların sorulan sorulara ilişkin verdikleri ilişkili yanıtlar kodlanmış, konu dışında kalan ilişkisiz bilgiler kullanılmamıştır.

\section{Bulgular}

OSB tanısı almış çocukları olan annelerin tanı alma ve okulöncesi eğitim döneminde karşılaştıkları sorunları incelemek amacıyla gerçekleştirilen çalışma kapsamında elde edilen bulgular alt temalar altında sunulmuştur. Bu bağlamda bulgular, tanı alma süreci, belirtileri fark etme ve tanı alma yaşı, tanılama sonrasında alınan özel eğitim ve rehabilitasyon hizmetleri, alınan özel eğitim hizmetlerinin niteliği ve okulöncesi eğitime erişimde karşılaşılan güçlükler başlıkları altında sunulmuştur. Okulöncesi eğitime erişimde karşılaşllan güçlükler ise çocuğun özelliklerine uygun okul bulmaya dair sorunlar, okul yönetimi ve öğretmenlere ilişkin sorunlar, kayıt esnasında karşılaşılan sorunlar, sınıf ortamına ilișkin sorunlar, normal gelişim gösteren çocukların ailelerinin OSB'li çocuğa yaklaşımına ilişkin sorunlar, okulöncesi eğitimin maddi maliyetine ilişkin sorunlar ve OSB'li çocukların eğitim sürelerine ilişkin sorunlar alt tema başlıkları altında detaylandırılmıştır.

\section{Tanı Alma Süreci}

Tablo 2'de görüldüğü üzere tanılama ve teşhis sürecinde anneler kendi şüpheleri ile yakın çevrelerindeki bireylerin ya da öğretmenlerin gözlem ve şüphelerinden yola çıkarak profesyonel desteğe başvurduklarını ve çocuklarına bu şekilde teşhis konulduğunu belirtmişlerdir. Örneğin, katılımcı annelerden (K7) bu süreçte çocuğunun gösterdiği davranışları şu şekilde tanımlamıştır: "Ben hep şüphelendim zaten... sekiz aylıkken doktora götürdüğümüzde doktorumuz 'Yok, yok.' dedi. Hatta 16 aylıken çocuk nöroloğu doktoru var Doktor B, Ç hastanesinde çalışlyor. Ona da ben o zaman yürüyemiyor diye gittim... 'Bakın doktor bey ben OSB'yi televizyondan da duyuyorum. Belirtileri de oğlum M'de var yani ne yazık ki.' dedim. Büyükannesi ilk başta 'imkânsız, olamaz, çok güzel dedesiyle iletişim kuruyor, OSB'li olan çocuklar iletişim kuramaz.' dedi... Ama yaş, ay ilerledikçe daha da belirginleşiyor. Sallanması var. Konuşması yaşıtlarına göre çok çok gerideydi. Kendi dünyasında, kimseyle ilgilenmeyen bir çocuktu."

Katılımcı annelerden bazıları ise çocuklarındaki dil, konuşma ve sosyal gelişim ile ilgili farklılıkları iki yaşından itibaren fark etmeye başladıklarını belirtmişlerdir. $\mathrm{Bu}$ 
durumu (K5) şu şekilde açıklamıştır: "Aslında iki yaşına kadar her şeyin normal gittiğine inanıyordum. İki yaşından sonra özellikle dil gelişimindeki gerilik, ismiyle hitap ettiğim zaman dönüp bakmaması, bizimle evdeki etkinliklerde zaman paylaşmak istememesi, birlikte oyun kurmaya çalıştığımızda tek başına vakit geçirmesi, diğer çocukların dikkatini çeken şeylerin onun dikkatini çekmemesi, aksine bizi şaşırtacak şeylere dikkat etmesi ve özellikle konuşmasındaki eksiklik." Benzer bir şekilde (K4) çocuğunda ilk fark ettiği gelişimsel sınırlılığın OSB'nin karakteristik özelliklerinden biri olan konuşma ile ilgili olduğunu ve bu şekilde tanı alma sürecinin başladığını belirtmiştir: "Şöyle oldu. Ben çocuğum T daha bir buçuk yaşındayken bir şeyler fark etmeye başladım. İlk tanımız... bizce konuşmamaya başladı, konuşmuyordu."

Tablo 2. Çocuktaki gelişimsel farklılığın fark edilmesi

\begin{tabular}{lcc}
\hline Fark eden kişi & F & $\%$ \\
\hline Kendi & 10 & 71.4 \\
Yakın çevre & 2 & 14.3 \\
Öğretmen & 2 & 14.3 \\
\hline Toplam & 14 & 100 \\
\hline
\end{tabular}

Bir diğer katılımcı annesi (K11) ise çocuğundaki farklılıkları diğer çocukları ile karşılaștırarak fark ettiğini şu șekilde belirtmiştir: “...Ben üç çocuk annesiyim. Öbür çocuklarımda görmedim bunları. Bir yaşındayken çocuklarım bana objeleri gösterebiliyorlardı. Benimle kelimeler çıkarabiliyorlardı. Gösterdiğim objeyi bana geri getirebiliyordu istediğim zaman, ama bu çocuğumda yok ... ve de aşırı sinirli hiperaktif bir çocuk." Başka bir katılımcı anne ise (K12) çocuklarında var olduğunu düşündükleri başka sorunlardan yola çıkarak OSB tanısına ulaștıklarını șu șekilde anlatmıștır: "Tam net yaşı iki buçuk ya da üç diyebiliriz... Yani ilk önce kulak burun boğaza gittik, duymuyor mu acaba diye... Kulak burun boğaz doktoru baktı. İșitme testleri yaptı hiçbir sorun yok... Sonrasında işte nörolojiye gönderdiler... Bu arada, çocuk alerji bölümünde doktor da baktı. Astım olduğu için. Aslında biz astımla alakalı gitmiştik hani. Nöroloji de baktı, Küpleri dizdirdi üst üste. On kere sesleniyor üçüne baklyordu o zaman o dönemde. Ísmine tepki çok az veriyordu. $O$ nöroloji de psikiyatriye gönderdi. Çocuk psikiyatristi de tanıyı koydu..."

Katılımcı annelerden ikisi (K1 ve K10), çocuklarını bir yakınlarının yönlendirmesi ile doktora götürdüklerini belirtmiştir. Katılımcı anne (K1) bu durumu şu şekilde açıklamıştır: "Eltimin kız kardeşi öğretmendi o anladı. Ondan sonra biz N merkezine gittik. Oradaki doktorlar, nörolojide ilk olarak beyin filmleri çektirdiler. EEG'si çekildi. Onlar çekildikten sonra tanısı konuldu. Her şey bir gün içerisinde pataküte oldu." Diğer iki katılımcı anne (K6 ve K13) ise çocuklarının tanı alma sürecinin öğretmenlerinin fark etmesi ve yönlendirmesi ile başladığını belirtmiştir. Örneğin, katılımcı anne (K6), erken dönemlerde birçok doktora başvurmasına rağmen anasınıfı öğretmeninin yönlendirmesi ile tanı aldıklarını șu şekilde açıklamıştır: "Çocukken bu çevrede çocuk pedagogu yok doğal olarak. Normal psikoloğa götürdüğümde ben D'yi konuşmuyor diye götürdüm. Ama doktor konuşacağını söyledi. D'de aslında belirtiler yoktu. OSB'de işte dönen nesneye bakma gibi şeyler sordu... En sonunda anasınıfına gönderdiğimde bariz diğer çocuklardan farklı olduğu davranışlar vardı. Anasınıfı öğretmenimizin yönlendirmesi ile özel bir hastaneye götürdügümde orada tanı koyuldu D’ye." Bir diğer katılımcı anne ise öğretmenlerinin yönlendirmesini şu şekilde ifade etmiştir: "Şimdi doğuştan epilepsi olduğu söylendi. Daha sonra burada eğitim alırken öğretmenleri fark etti OSB olduğunu. Yani iki yaşındayken... Daha sonra da çocuk psikiyatristi OSB olduğu tanısını koydu." 


\section{Belirtileri Fark Etme ve Tanı Alma Yaşı}

Çalışmaya katılan 8 anne $(\% 57,1)$ çocuklarının gelişimlerindeki farklılığı 2 yaş öncesinde fark ederken, 5 anne (\%35,7) 2-4 yaş arasında ve 1 anne de $(\% 7,1)$ beş yaşında fark ettiğini belirtmiştir. Tanı alma yaşı bağlamında ise, 9 anne $(\% 64,3)$ çocuklarının 2 -4 yaşları arasında tanı aldığını belirtirken, 4 anne $(\% 28,6)$ çocuklarının 0 -2 yaşları arasında tanı aldığını belirtmiştir. Bir anne $(\% 7,1)$ ise çocuğunun 5 yaşındayken tanı aldığını rapor etmiştir.

\section{Tanılama Sonrasında Alınan Özel Eğitim ve Rehabilitasyon Hizmetleri}

Tanı alma sonrası OSB'li çocukların özel eğitim ve rehabilitasyon merkezlerine devam ederek özel eğitim hizmetlerinden yararlanması ve eş zamanlı olarak normal gelişim gösteren akranlarının bulunduğu eğitim ortamlarına devam etmesi gelişimleri açısından oldukça önemlidir. Tablo 3'te görüldüğü gibi katılımcı anneler, OSB tanısı almasından sonra çocuklarının okulöncesi dönemde özel eğitim ve rehabilitasyon merkezlerine devam ettiklerini, bir kuruma devam etmeden sadece dil ve konuşma terapisi hizmetlerinden yararlandıklarını ya da gündüz bakım sağlayan kreşlere devam ettiklerini belirtmişledir. Bir anne ise aldıkları özel eğitim hizmetlerine ek olarak alternatif birçok yöntemi denediklerini rapor etmiştir. Bu veriler incelendiğinde, çocuklardan sadece üçünün bir özel eğitim ve rehabilitasyon merkezine devam ederken ya da terapi hizmeti alırken aynı zamanda normal gelişim gösteren akranlarının bulunduğu ortamlara erişim sağladığı görülmektedir.

Tablo 3. Tanılama sonrasında alınan özel eğitim ve rehabilitasyon hizmetleri

\begin{tabular}{lcc}
\hline Hizmet & $\mathrm{F}$ & $\%$ \\
\hline Özel eğitim ve rehabilitasyon & 13 & 76.5 \\
Dil terapisi & 1 & 5.9 \\
Kreş eğitimi & 3 & 17.6 \\
\hline
\end{tabular}

Özel eğitim ve rehabilitasyon merkezlerinden destek eğitim hizmetleri aldıklarını belirten anneler, bu kurumlarda çocuklarının dil ve konuşma becerilerinin desteklenmesinin yanında akademik becerileri üzerinde de çalışıldığını belirtmişlerdir. Örneğin, katılımcı anne (K1) bu durumu şu şekilde açıklarken, "Devam ettiğimiz kurumdaki öğretmenlerden biri tamamen çocuğum R'yi konuşma ve sosyal olarak açma odaklı çalışıyordu. Diğer öğretmende tamamen akademik çalışıyordu." bir diğer katılımcı anne, (K2), deneyimlerini şu şekilde özetlemiştir: "Burada bireysel artı grup desteği alıyor. Dil terapisine yeni başladık. Dil çalışmaları yapılıyor zaten konuşmamız var cümlemiz de var. Açık bir çocuk dediler. Burada bireyselde renkler, şekiller üzerinde çalışıyor. Alıcı dil alıyor bir de..."

Özel eğitim ve rehabilitasyon merkezindeki bir uzmanın önerisiyle çocuğunu önce kreşe daha sonra da özel okula göndermeye başlayan katılımcı annelerden (K4) deneyimlerini şu şekilde özetlemiştir: “...Üç buçuk yaşındayken Uzman O okula ver dedi, ama içime sinmedi. Kreş gibi. Hiç içime de sinmedi ama çocukta da açılma var diye devam ettim... Dört yaşında özel bir okula verdim. Güzel, iyi bir okuldu. Psikoloğu falan var bize birebir eğitim vereceklerdi. Psikolog 15 gün sonra dedi ki sizin oğlunuz sosyal olarak uyumlu bir çocuk onların yaptığını yapmaya çalışıyor ama dedi özel eğitim alanında çocuk çok yetersiz dedi. Siz buraya boşu boşuna para yatırmayın, bu parayı özel eğitime harcayın dedi. Yani özel eğitim alsın dedi. Ben bir özel eğitim merkezi buldum. Sonra kız kardeşim duyu bütünleme eğitimi buldu işte ona başladım. Konuşmayanlar konuşuyor deyip oraya gittik. Oraya başladığında çocuğum M'nin korkuları endişeleri vardı. O duyu bütünleme bize çok 
çok iyi geldi. Yani o hocayla devam etseydik bugün başka bir yerde olurduk zaten." Çocuğu hem özel eğitim ve rehabilitasyon merkezine hem de kreșe devam eden bir anne ise bu süreci şu şekilde açıklamıștır: "Yaz tatili girdi araya memlekete gittik. Hani orda çocuklarla vakit geçirsin diye. Sonra bireysel eğitimimiz başladı. Kreşe vermedik. Vermeyin dediler bize. Biraz daha toparlasın kendini. Orda kendini ifade edemediği için daha çok içine kapanacağını söylediler. Buraya başladıktan beş ay sonra artık kreşe gidebilir dediler. Biz de öyle başladık." Benzer şekilde, uzman önerisi üzerine, çocuğu hem kreșe hem de özel eğitim ve rehabilitasyon merkezine devam eden başka bir anne ise, (K7), bu durumu şu şekilde açıklamıştır: "Psikiyatristimiz kreșe başlamasını tavsiye ettiği için temmuz ayında kreșe gönderdik. Sonrasında eylülde tekrar kreșe devam etti. Birkaç ay sonra görüşmemizde psikiyatristimiz dedi ki gelişme var ama istediğim ölçüde değil zaman kaybetmek istemiyorum. Özel eğitimle de desteklerseniz daha iyi olur dedi. Sonrasında şubat ayında özel eğitim başladık. Yani oğlum üç yaşındayken özel eğitime başladık."

Çocukları OSB gibi özel gereksinim tanısı alan ailelerin birçoğu sahip oldukları özel gereksinimlerin çocukları üzerindeki etkilerinin azaltılması için özel eğitim ve rehabilitasyon hizmetlerine ek olarak alternatif yollar arayabilmektedir. Katılımcı annelerden (K11), bu bağlamda yaşadıkları deneyimi şu şekilde açıklamıştır: "Cerrahpaşa 'ya gittim. A' ya gittim. Diyet falan yaptık. Özel damlalar falan kullandık, balık yağı falan kullandık. Zihni berraklaştırmak için yosun damlası falan özel damla kullandık, diyet yaptık. Ondan sonra rapor çıkarttırdık. Eğitime devam ettik."

\section{Alınan Özel Eğitim Hizmetlerinin Niteliği}

Çalışmaya katılan annelerin 5'i (\%35,7) aldıkları eğitim hizmetlerin kalitesini yetersiz olarak değerlendirirken, 6’sı (\%42,9) eğitim hizmetlerinin geliştirilebilir, 4'üde $(\% 21,4)$ yeterli olduğunu belirtmiştir. Çocuğu OSB tanısı aldıktan sonra aldıkları özel eğitim ve rehabilitasyon hizmetlerini yeterli bulan dört katılımcı anneden bir olan K3, aldıkları eğitim hizmetleri sayesinde çocuğunun birçok yeni beceri kazandığını şu ifadelerle dile getirirken "İlkin hiç göz teması yok gibiydi. Gel dediğim zaman gelmezdi. Şimdi evden çıktığım zaman gel dediğim de elim tutup geliyor... Mesela ilkin ağladığı zaman susmuyordu. Şimdi bu sus işaretini anlıyor." özel eğitim hizmetlerinden memnun olan bir diğer annede, (K12), şunları söylemiştir: "O dönemde ilk altı ay içinde yapılan dil ve konuşma çalışmaları çok faydalı oldu. Öfke nöbetleri çoktu Ö'de. Onlarda da azalma oldu zamanla. Evet kurumdan memnun kaldım kesinlikle."

Aldıkları özel eğitim hizmetlerinin iyi olduğunu ancak bu hizmetlerin geliştirilebileceğini belirten annelerden üçü temel olarak sunulan eğitimin kalitesinden memnun olduklarını ancak çocuklarının daha fazla eğitime ihtiyaç duyduklarını belirtmişlerdir. Bir anne, (K1), çocuğuna sunulan eğitim oturumlarının azlığını "Evet, uzmanlarımızın iyi uzmanlar olduğunu düşünüyorum sadece belki daha fazla olsaydı şu an farklı bir pozisyonda olabilirdik. Seanslarımız azdı." șeklinde dile getirirken bir diğer katılımcı anne, (K2), şunları belirtmiştir, "Keşke devlet daha çok karşılasa da haftada 2 gün mesela bireysel alıyor. Keşke iki değil de dört gün alsak beş gün alsak. Hani çocuğun yoğunluğuna göre, her çocuk kaldırabilir mi bilmiyorum ama mesela yurtdışında Amerika'da özellikle 16 saat, 32 saat alan çocuklar varmış." Bir diğer anne de, (K10), "... eğitimlerden memnunuz ancak...yeterli değil, ders saatleri az bunların, her gün gelmesi lazım o da yok." şeklindeki söylemiyle sunulan eğitim hizmetlerinin artırılması gerektiğini vurgulamıştır.

Çocuklarına sunulan özel eğitim ve rehabilitasyon hizmetlerinden memnun olmayan, bu hizmetleri yetersiz bulan altı annenin sorulara verdikleri cevaplar incelendiğinde OSB'li çocukların eğitimi ile ilgili süregelen bazı sorunlara değindikleri görülmektedir. 
Örneğin, katılımcı anne (K4), özel gereksinimli çocuklarla çalışan uzmanların OSB konusunda sınırlı düzeyde bilgi sahibi olmalarını şu ifadelerle dile getirmiştir, "illk öğretmenimizden hiç memnun değildik.... Çünkü OSB'yi o da bilmiyordu. Yani biz anlatıyorduk ama o bilmiyordu. Diğer çocuklarla aynı kefeye koyuyordu çocuğumu." Bir diğer katılımcı anne ise, (K6), devlet tarafından ücreti ödenen özel eğitim ve rehabilitasyon hizmetlerinin yetersizliğini şu şekilde belirtmiştir, "Bence yetersiz. Şimdi gidiyoruz çocuk psikiyatristinin bize söylediği ne kadar yoğun bir eğitim, o kadar iyi bu çocuklar için. Ama devletin sağladığı zaten belli bir aylık saat var. Eğitim saatini yetersiz buluyorum... Ama neden bu konu bu kadar az veriliyor onu ben bilmiyorum tabii ki." Benzer şekilde başka bir katılımcı anne de (K7), özellikle devlet tarafından ücreti ödenen eğitim saatlerinin azlığından dolayı eğitim hizmetlerini yetersiz bulduğunu belirtmektedir, "Yetersiz yani. Devletin verdiği 10-12 saatte ne yapılabilir ki... Devletin verdiği özel eğitimin iki katını da ben özel olarak aldırdım M' ye birebir. Yetersiz diye." Bir diğer katılımcı anne ise, K8, eğitim oturumlarının süresinin daha uzun olması gerektiğini vurgulamıştır, “...Keşke biraz daha uzun olabilseydi diyorum hani. Eğitim 45 dakika değil de keşke hani daha fazla olsaydı 1 saat ya da 2 saat mesela."

\section{Okulöncesi Eğitime Erişimde Karşılaşılan Güçlükler}

Tablo 4'de görüldüğü gibi çalışmaya katılan anneler okulöncesi eğitime erişim bağlamında birçok farklı güçlükle karşı karşıya kaldıklarını belirtmişlerdir. OSB olan çocukların, annelerinin ve ailelerinin okulöncesi eğitim sürecinde yaşadıkları güçlüklerin her biri ile ilgili bulgular aşağıda ayrı başlıklar altında açıklanmıştır

Tablo 4. Ailelerin okulöncesi eğitime erișimde karșılaștıkları güçlükler

\begin{tabular}{lcc}
\hline Güçlük & $\mathrm{F}$ & $\%$ \\
\hline Çocuğun özelliklerine uygun okul bulmaya dair güçlükler & 7 & 50 \\
Okul yönetimi ve öğretmenlere ilişkin sorunlar & 9 & 64.3 \\
Kayıt esnasında karşllaşılan sorunlar & 6 & 42.9 \\
Sinıf ortamına iliş̧in sorunlar & 6 & 42.9 \\
Normal gelişen çocukların ailelerinin OSB'li çocuğa yaklaşımına ilişkin & 1 & 7.1 \\
sorunlar & & 7.1 \\
Okulöncesi eğitimin maddi maliyetine ilişkin sorunlar & 1 & 35.7 \\
OSB'li çocukların eğitim sürelerine ilișkin sorunlar & 5 & \\
\hline
\end{tabular}

Çocuğun Gelişim Özelliklerine Uygun Okul Bulmaya İlişkin Karşılaşılan Güçlükler. Katılımcı anneler, OSB'den etkilenmiş çocukları için uygun okulöncesi eğitim kurumları ve sınıfları bulmakla ilişkili yaşadıkları en önemli güçlüğün okulöncesi kurumlarının engelli çocuk kabul etmek istememeleri olduğunu belirtmişlerdir. Örneğin, katılımcı anne, (K1), karşılaştıkları bu durumu şöyle özetlemiştir, "Bir okula gittim çocuğum OSB'li olduğu için kabul etmediler. Bizim için problem olmuyor ama diğer çocukların velileri istemiyor dediler. Biz dört farklı okula gittik. Böyle çocukla daha önce ilgilenmediklerini, hiç tecrübeleri olmadiğını, daha çok butik okullara götürmemiz gerektiğini söylediler. Butik okullara götürdügümüz zaman da bizim şu an kontenjanımız doldu, öğrenci alamiyoruz dediler. Ya da gölge öğretmeni söylediğimiz zaman ekstra okulumuz dışında bir ögrretmen kabul etmiyoruz dediler. Bunlar hep bir bahaneydi net bir şekilde belliydi. Ben de alelacele gölge öğretmensiz çocuğumu zaten teslim etmek istemedim. İnternetten liste yaptım. Gittim R ile beraber gözlem yaptım en iyi okulu belirlemek için."

Benzer șekilde bir diğer katılımcı anne de, (K2), çocuğunun yaşından, OSB raporu oluşundan ve tuvalet eğitimi olmayıșından dolayı okulöncesi kurumuna alınmak istemediğini belirtmiştir. Bu anne deneyimlerini şu şekilde tanımlamıştır, "Şimdi bizimkisi 
küçük olduğu için biz özel anaokuluna başladık. Devlet anaokulu almıyordu zaten bizi. Íki buçuk yaşında başladık. O zaman raporu çıkmamıştı bir sorun yoktu. Ama raporlu olduktan sonra özel anaokulu arayışına girince, raporunu direkt duyunca almayan, istemeyen okullar oldu özel olduğu halde. Diğer çocukların annelerinin tepkilerinden çekindiler veya çocuğun o zaman tuvalet eğitimi yoktu, bezleniyordu. Ama iki buçukyaşında birçok çocuk bezleniyor. Yani almak istemediler. Sonra biz bir okul bulduk. $O$ da şöyle. İlk önce ben çocuğumla gittiğim; çocuğum zaten çok sakindi. Zaten çok öyle ağır OSB'li olmadığı için çok hafif. Bir bırakın dediler. Bir iki saat çocuğu bir gözlemleyelim dediler. Sınıftaki diğer çocuklarla uyumuna bakalım dediler. Tamam dedim. Ondan sonra kabul ettiler."

Başka bir katılımcı anne, (K7), okulöncesi kurumlarının uygun personeli olmaması nedeniyle çocuklarını okula almak istemediğini belirtmiştir: "Birkaç anaokuluyla görüştüm ben. Çoğu anaokulunda ya da kreşte özel eğitim uzmanı kadrosu zaten yok. Bu tür çocuklar rehabilitasyon merkezine yönlendirilip özel eğitimi destekleyebilecek birilerine yönlendiriliyor sadece. Kreşlere ya da anaokullarına özgü çalışan bir uzman yok. Ama özel bir anaokuluna gidiyor benim oğlum. Sınıfları kalabalık değil birazcık da hani ne kadar öğrenci sayısı az olursa o kadar ilgilenme zamanı fazla olur diye düşündüm. Sekiz-on kişilik sınıfları var. Ama özel eğitim konusunda ben kreşin oğlumu desteklediğini düşünmüyorum. Sadece kreşe gönderme amacım sınıfta konuşan arkadaşlarıyla iletişim halinde olsun, gözlemlesin. En azından sosyal anlamda paylaşım olsun istedik."

Çalışmaya katılan annelerden ikisi, (K4 ve K5), çocuklarına okulöncesi eğitim kurumu bulmakta zorlanmadıklarını belirtmişlerdir. Örneğin, katılımcı anne, (K4), bu durumu, "O konuda ben hiç sıkıntı çekmedim okullarda. Kaynaştırmaya gidiyor M şu anda zaten." şeklinde açıklarken, K5 bu durumu, "Okulu iyi bir yer olsun diye iyi bir yere verdik. Orda da benim kaygılarımın olduğunu anlattım ama herhangi bir sıkıntı olmadığını söylediler çocuğum $T$ için. Çocuklarda olabilecek durumlar olduğunu söylediler." şeklinde özetlemiştir.

Okul Yönetimi ve Öğretmenlere İlişkin Güçlükler. Katılımcı anneler, öğretmenlerin ve okul yöneticilerinin OSB'li çocuklara karşı sergiledikleri olumsuz bakış açısının ve OSB ile ilgili bilgi eksikliklerinin en sık yaşadıkları sorunlardan biri olduğunu belirtmişlerdir. Örneğin, katılımcı anne (K2) bu durumu şöyle özetlemiștir, "Şu an devlet okuluna vereceğim çünkü dört yaşına geldi ama tuvalet eğitimi olmadığı için almak istemeyecekler biliyorum. Sorun yaşatacaklar yine OSB'li olduğu için. Birçok öğretmen zaten OSB nedir bilmiyor. Biz de evet bu işin içine girince anladık ama onlar eğitimci. Öğrenmeleri gerekiyor. Bu konuda bilgi yok denecek kadar çok az. Yani 100 öğretmenden belki on tanesi ancak biliyor. OSB deyince çok farklı bir kalıba sokuyorlar. OSB içinde çok zeki olan çocuklar da var ki benim çocuğum da zeki gerçekten. Ben biliyorum davranışlarından falan ama OSB deyince onlar direkt zihinsel engelli işte sağa sola zarar veren çocuklar gibi algılandığı için almak istemiyorlar."

Diğer bir anne, (K6), öğretmenin OSB'li çocuğuna karşı takındığı tavrı şu şekilde açıklamıştır; "Ben çocuğum D'yi ilk anasınıfına yazdırdığımda daha bir tanı koyulmamıştı. Ben de sosyalleşmesi için bir okula yazdırdım. Devlet okulunun anasınıfına yazdırdım. D orda resmen dışlandı. Nasıl dışlandı? Bence öğretmen faktörü çok önemli. Onu nasıl desem, bilincinde olması gerekiyor. Her gittiğimde D masanın orda tek başına oturmuş. Ben her akşam öğretmenden şikâyet alıyorum. D su döküyor, D oyunlara katılmıyor. D elini klozete sokuyor, hiç yapmadığı davranışlardan bahsediyor. OSB'yi birakın zaten bir teşhis konulmamıştı. Normal kaynaştırma öğrencisi alınması gereken her okul alması gerekiyor." Katılımcı anne, K9 da çocuğunun hareketli olmasından dolayı öğretmen tarafından kabul edilmeyişini şu ifadeler ile dile getirmiştir: "Anaokuluna başlayamadık. Öğretmen hareketli olduğu için ben yapamam dedi. Bende bekleyebilirim dedim birkaç saat dursun, 
çocukların içinde olsun dedim ama çok hareketli yapamam dedi. Anaokulu almayınca iki yıl kreşe gönderdim. Krește hocalar iyiydi ama istediğim verimi alamadım."

Çalışmaya katılan anneler, öğretmenlere ek olarak yöneticilerin OSB'li çocuklara karşı sahip oldukları olumsuz bakış açısının, çocuklarının okulöncesi eğitime erişimlerin önünde bir engel olduğunu belirtmişlerdir. Örneğin, katılımcı anne, (K6), bu durumu “Ben okul müdiresine öğretmenin davranışlarını anlattım. En önemlisi müdür yardımcısının beni çağırdığında bana işte bu çocuk çok sorunlu, böyle bir konuşma tarzı. O gün hayatım boyunca hiç unutamayacağım bir gündü. Çok sorunlu alın çocuğunuzu nereye götürürseniz götürün diye bir konuşma tarzı. Anlatamam, o gün okuldan çıkıp eve gittiğimi hatırlamıorum bile. Gerçekten hatırlamiyorum ben. İlkokul deneyimimiz faciaydı. Sonra benim kardeşim bir eğitimci onun bulduğu bir öğretmenle iki yıldır oraya gidiyor anasınıfına." şeklinde açıklamıştır.

Çalışmaya katılan anneler, sınıflarda karşılaştıkları sorunlardan bir diğerinin de öğretmenlerin çocuklarını sınıftaki diğer çocuklardan ya da sınıf etkinliklerinden ayrı tutması olarak tanımlamışlardır. Bu nedenle çocuğunun okulunu değiştirdiğini belirten katılımcı anne (K5) gözlemlediği problemi şu şekilde açıklamıştır, "Daha önceki okulumuzda çok sorun yaşadık o yüzden değiştirmek durumunda kaldık. Mesela şey yapıyorlardı. T'yi hep diğer çocuklardan ayırt ettiklerini gördüm. Hani bu bir geçiş dönemi sınıfa alacağız falan diyorlardı ama T’nin başına birini veriyorlardı. Çocuk akşama kadar top havuzunda oynuyor. Biz bunu istemiyoruz. Bizim amacımız zaten arkadaşlarlyla beraber olması ve uygun eğitim alması. Sonra sınıfa aldıklarında T'nin hareketli olduğunu sınıf düzenini bozduğu yönünde bir şeyler söylüyorlardı. Öyle de olunca biz ister istemez geri çekiliyorduk." Çocuğunun devam ettiği okulda benzer deneyimler yaşayan katılımcı anne (K1) ise başından geçenleri, "Önceki gittiği okulda bir haftalık bir deneme süreci geçirdim. Birincisi sınıftaki öğretmenlerin çocuklara karşı çok soğuk olduğunu gözlemledim. Belki iyi biri eğitim verebilir ama çocuklara sevgi ve şefkat göstermedi. Cocukların sıcak bir ortamda olduğunu düşünmedim. Bir diğer okulda, çocuğum R'yi ă̆zına bir parça oyun hamuru attığı için farklı bir masaya oturttular ve farklı bir hoca verdiler. Üç gün daha sabredebildim." şeklinde özetlemiştir.

Çalışmaya katılan annelerden ikisi, (K4 ve K11), çocuklarının devam ettiği okulöncesi eğitimi kurumundaki yöneticilerin ve öğretmenlerin çocuklarına karşı çok olumlu olduklarını belirtmişlerdir. Örneğin, katılımcı anne, (K4), "Şu anki okulda herhangi bir sıkıntı yaşamadım. Müdür bizim gibi düşünüyordu. Müdür diyordu ki ben çocuğum M'yi takip ediyorum. Teneffüslerde koşuyorsa oynuyorsa bu zaten kaynaştırma çocuğu. İstediğimiz bu yani." Katılımcı anne (K11) de okulöncesi kurumlarında yaşadığı olumlu deneyimleri şu şekilde ifade etmiştir, "O çok tatlı bir çocuktu yani çok sevecen bir çocuk olduğu için hep seviliyordu sıkıntı yaşamadım çok göze batan hareketleri yoktu farklı hareketleri yoktu O'nun sadece hiperaktifliği vardı konuşma güçlüğü vardı. Öğretmenimiz hamile olduğu için biraz yıpranıyordu ama başka hiçbir sorun yaşamadım hiçbir öğretmeniyle çok sevildi hep."

Kayıt Esnasında Karşılaşılan Güçlükler. Çalışmaya katılan anneler, OSB'den etkilenmiş çocuklarını okulöncesi eğitimi kurumlarına kaydettirirken bazı güçlükler yaşadıklarını rapor etmişlerdir. Katılımcı annelerden biri, (K2), okulların kendilerini geri çevirdiğini ya da yöneticilerin kayıt öncesi mutlaka çocuğu görmek istediklerini belirtmiştir, "Okula kaydettirmeye çalışırken direkt beni güzel, kibar bir dille geri çevirdiler. Çocuğumun OSB'li olduğundan dolayl. Mesela şimdi spora vermek istiyorum... yüzmeye vereceğim devlete ait. Bir sorun yaptılar... Çocuğu yanımda götürmüştüm. Orda yetkiliyi buldum. Anlattım çocuğun raporunda geçici olduğunu, Ekim'de biteceğini. Çocuğu getirin, 
spor hocası görsün dediler. Yani hep bir deney gibi çocuğu görmek istiyorlar, anladınız mı bakacaklar. Onun için çocuğumuzu oraya, buraya, kişilere götürmek zorundayız."

Bir diğer anne, (K9), ise çocuğunun hareketli olmasından dolayı öğretmen tarafından sınıfa kabul edilmediğini ve dolayısıyla okula kaydının yapılmadığını belirtmiştir, "Anaokuluna başlayamadık. Öğretmen hareketli olduğu için ben yapamam dedi. O yüzden iki yıl kreşe gönderdim. Krește kabul ediyorlardı zaten ama normal devlet okuluna göndermedim. Krește hocalar iyiydi ama istediğim verimi alamadım." Başka bir anne de (K12), OSB tanısı alan çocuklarını devlet okullarına kaydettirebilmek için tanıdık birini bulmak durumunda kaldıklarını şu ifadeler ile dile getirmiştir, "İlk önce raporu çıktığında yarım dönemdeydi. Okulun ikinci dönemiydi hiçbir okul almıyordu. Biz Milli Eğitimden tanıdık vasıtasıyla kontak kurduk işte oradan aldırmaya çalıştık ama öğretmenin de inisiyatifi biliyorsunuz hani kaynaştırma öğrencisi iște 25 kişilik sınıfa en fazla bir veya iki öğrenci alabiliyor herhalde. $O$ dönemde tabii Ö'de hırçınlık olduğu için kendini ifade edemediğinden dolayı sorun yaşandığı için diğer arkadaşlarıyla problem yaşamasın diye bir saatliğine alıyorlardı sonra iki saate çıkardı ama o dönem öyle boş geçti yani."

Çocuğunun OSB ilişkin sahip olduğu sınırlılıkları hafif düzeyde olan bir anne ise okula kayıt sırasında herhangi bir sorun ile karşılaşmadıklarını rapor etmiştir. Anne, (K4), bu durumu şu şekilde açıklamıştır, "İlk başta endişeliydi ama M uyumlu olduğu için sıkıntı yaşamadık diyebilirim. Veliler sağ olsunlar çok anlayışlılar arada bir birkaç çocuğun canını acıttı ama veliler sağ olsun bana üzülme dediler yani o derece iyi insanlardl."

Sınıf Ortamında Karşılaşılan Güçlükler. Çalışmaya katılan anneler, OSB'den etkilenmiş çocuklarının okulöncesi eğitim sınıflarına yerleştirildiklerinde de bazı güçlüklerle karşılaştıklarını belirtmişlerdir. Katılımcı anneler, arkadaşlarının çocuklarına yaşıtları gibi değil de bebekmiş gibi davrandıklarını ya da çocuklarının başka alanlarda akranlarından ayrı ortamlarda tutulduğunu belirtmişlerdir. Örneğin, katılımcı anne, (K2), bu durumu şöyle açlklarken, "Bizim çocuk çok fazla onlar gibi konuşamıyor. Eee tabii kendini ifade edemediği için çocuklar mesela genelde kız çocukları...teneffüslerde diyorlarmış ki "aaa bu da bebek gibi konuşamıyor" hani bizim çocuğa bebek gibi yaklaşıyorlarmış. Elinden tutup oyunlara falan sokuyorlarmış. Ama yașıtları gibi değil de hani kendisinden küçük gibi görüyorlarmış.", bir diğer anne de (K10), deneyimlerini şu şekilde dile getirmiştir, "“Okulu RAM'dan yönlendirdiler, başladık çocuğu götürdüm hiç öbür çocuklarla uyum sağlamadı. Ondan sonra zaten bir oyuncak odası vardı çocuğumu ayrı bir odada oynatlyorlardı. Diğer çocukların arasına girmiyordu."

Katılımcı annelerden ikisi, okulda yaşadıklarından dolayı, çocuklarının okula gitmek istemediklerini belirtmişlerdir. Örneğin, katılımcı anne, (K4), bu durumu, "Kaynaştırmaya verdim ya haliyle de normal çocuklar gibi farkında şu anda mesela 1.sınıfa gidiyor. Anne diyor ben niye okula gideyim ki diyor. Ben okumayı bilmiyorum, yazmayı bilmiyorum.", şeklinde açıklarken, K6 deneyimlerini şu şekilde rapor etmiştir, "Çocuğum inanır mısınız hala okula gitmek istemediğini söylüyor. Artık orada ne oluyor bilmiyorum ama... Gitmek istemiyor. Öğretmenini çok seviyor ama D'yi okula hazırladığımda istemiyorum deyip bana her seferinde bir tepki gösteriyor."

Normal Gelişim Gösteren Çocukların Aileleri ile İlgili Durumlar. Çalışmaya katılan annelerden biri, (K2), çocuklarının eğitim gördüğü okulöncesi sınıfındaki çocukların aileleri ile okul yönetiminin tutumu nedeniyle güçlük yaşadığını şu şekilde açıklamıştır: "Şimdi onu gizli tuttular. Özel okul olduğu için problem yaşamadım. Ama diğer ailelere çocuğumun OSB'li olduğunu söylemedi okul. İstemiyorlar çünkü bulaşıcı olacağını mı düşünüyorlar, çocuklarına zarar vereceğini mi düşünüyorlar. Dışlıyorlar yani çocuk bile dışliyor." 
Bir diğer katılımcı anne, (K11), ise çocuklarının normal gelişim gösteren akranları ile yaşadıkları sorunları aileler ile birlikte çalışarak nasıl çözdüklerini şu şekilde açıklamıştır, “ $O$ ' dan yana onlar pek bir şey görmediler. $O$ onlardan yana gördü yani O'yu oyunlarına katmak istemediler konuşmadığı için dışladılar hala da yaptıkları zamanlar oluyor çocukların. Ama velilerin yardımıyla aştık onları. O çok sevilen bir çocuktu veliler tarafindan da kendi çocuklarını sürekli uyarıyorlardı O’yu ilgili oyuna almaları için.” Katılımcı anne, (K7), ise okulöncesi dönemde normal gelişim gösteren çocukların aileleri ile çok güçlük yaşamadıklarını ancak bu durumun ilkokul yıllarında başladığını şu şekilde dile getirmiştir, "Aileler bir sıkıntı çıkarmadı. Bu ailelerin sıkıntı çıkarması daha çok ilkokul çağında oluyor. Çünkü kreșe gönderilen çocuklar için konuşacak olursam, çoğu anne baba çalıştığı için bakacak kimse olmadığı için birakmak zorunda kalıyor kreşe. Bir de çalışmadığı halde ya da çalıştığı halde çocuk sosyal alanda gelişsin diye gönderen bir potansiyel var o yüzden bu yaş gruplarında çok sıkıntı çıkarmıyorlar. Yani OSB'li çocuğun sınıfında bulunması hani benim çocuğumu rahatsız eder mi falan durumu yaşamadık."

Katılımcı annelerden ikisi, öğretmenlerin OSB'li çocuklara karşı tutumlarının normal gelişim gösteren çocukların ve ailelerinin tutumlarını etkilediğini belirtmişlerdir. Örneğin, katılımcı anne, (K4), bu durumu şu şekilde özetlemiştir, "O öğretmenden kaynaklanıyor zaten diye düşünürdü. Öğretmenimiz ilk bașta dedi. M'den dolayı bana şikâyete dedi kimse gelmesin dedi. Ben bunu velilerden duydum öğretmenden değil. Ĕger dedi M'den şikayetçi olan olursa kendi çocuğunu başka sınıfa alsınlar. Çünkü M çok zarar veren bir çocuk değil. Mesela üç saat okulda kalıyor M. Tüm ailelerden olumlu bir tepki aldım. Yani hepsi bana teselli verdi aileler." Bir diğer anne, (K5) ise benzer deneyimlerini "T yeni kreşinde bir arkadaş edinmiş kendine. Onu demek ki o kadar çok sevmiş ki sıkmaya başlamış. Sevgisini öyle gösteriyor. Bu kez de çocuk kendini geri çekmeye başlamış... Öğretmenimiz birebir ilgilenmeye çalışıyor. Diğer çocukların aileleri ile şu an yeni ya bir sıkıntı yaşamadık bir buçuk aydır. Kimsenin ailesiyle de görüşmedik işin açıkçası daha yeni. Toplantımız falan da olmadı toplu." şeklinde dile getirmiştir.

Okulöncesi Eğitimin Maliyetine İlişsin Sorunlar. Çalışmaya katılan annelerden biri, (K3), okulöncesi eğitimin maliyetli olması nedeniyle çeşitli güçlükler yaşadıklarını belirtmiştir. $\mathrm{Bu}$ anne, okul kabul etse bile, özel okulöncesi eğitim hizmetlerinden yararlanmanın maliyetli olduğunu şu şekilde dile getirmiştir: "Eşime de diyorum bu çocuk 24 saat evde olmaz. Gidelim, araştıralım. Özel okul olur, durumumuzu anlatıp bir iki milyar verip gidip konuşalım bir yerlerle diyorum. Parayı hesap etmem diyor ama geçenlerde bir yerden anaokulu kartı aldım. 900 liraymış. Bunu da eşimle konuştum. Veremeyiz o kadar diyor... Ben çocuğumun okula gitmesini istiyorum. Buraya geçenlerde bir kreş öğretmeni geldi. İki, üç, dört yaş arasında alıyoruz dediler. Ben de konuştum. Bizim çocuğa da uygun olur mu, benle gidip bir müdürle konuşsak nasıl olur. Gelin konuşun dediler ama yapamadık. Kreş öğretmeni, evden alıyormuş ama nasıl olacak valla çok kötü durumdayız. Kendim görüşemiyorum, eşim olmayınca. Eşim de gitmeye gider ama parayı hesap ediyor."

Okulöncesi Eğitimin Süresine İlişkin Sorunlar. Çalışmaya katılan anneler, çocuklarına özellikle devlet tarafından sağlanan eğitim sürelerinin kısalığından dolayı güçlükler yaşadıklarını belirtmişlerdir. Katılımcı annelerden biri, (K5), bu durumu şu şekilde ifade etmiştir: "Bireysel eğitim olarak bizim saatimiz çok az. Yani biz bu konuda çok mağduruz. Bu tarz çocuklarda yoğun eğitime ihtiyaç olduğunu biliyoruz. Haftada iki saat çok az bizim çocuklarımız için. Tam da yaşı küçük. Dört-beş yaşta ne kadar alırsa o kadar iyi ama bu yaşta bizim çocuklarımız haftada bir saat iki saatle olmuyor... Hani ben kreşe gönderiyorum çocuğumu ama kreşe gidemeyen çocuklar da var." Diğer bir katılımcı anne, (K6), da bu konudaki görüşlerini şu şekilde ifade etmiştir, "Eğitim süresini yetersiz buluyorum. Bence tam gün olsa daha iyi olmaz mi? Bir anne olarak öyle düşünüyorum. 
Uzmanların söylediği de o. Ama neden bu konu bu kadar az veriliyor onu ben bilmiyorum tabiiki." Başka bir katılımcı anne ise, (K12), kaynaştırma eğitimine devam eden OSB spektrum bozukluğundan etkilenmiş çocuğunun normal gelişim gösteren akranları ile birlikte geçirdiği zamanın sınırlı olmasını şu şekilde dile getirmiştir: "Kayıt öncesinde zaten raporlu diye hani kaynaştırma öğrencisi oluyor. İlk önce bir saatle başlayalım dediler, günde bir saat alalım. Bezli değildi çocuk tuvalet alışkanlığını öğretmiştik, konuşmuyordu ama, dört yaşındaydı... Hiçbir verim alamadık. Bir saatten iki saate yükseltemedik o dönemi."

\section{Tartışma}

$\mathrm{Bu}$ çalışmada, OSB'den etkilenmiş çocukların annelerinin çocuklarının tanı alma ve okulöncesi eğitim hizmetleri sürecine ilişkin deneyimleri incelenmiştir. Genel olarak, çalışmanın bulguları, annelerin çocuklarının tanı alma sürecine kendi istekleriyle, bir yakınlarının ya da çocuklarının öğretmenlerinin yönlendirmesiyle girdiklerini ve tanı alma sürecinin genellikle 2-4 yaş aralığında tamamlandığını ortaya koymuştur. Bulgular ayrıca, tanı alma süreci sonrası çalışmaya katılan tüm çocukların özel eğitim ve rehabilitasyon hizmetlerinden yararlanmaya başladıklarını ancak bu hizmetlerin kalitesinin yeterli olmadığını, dahası OSB'den etkilenmiş bu çocukların okulöncesi eğitime erişimde birçok güçlükle karşılaştığını ortaya koymuştur. Bu kısımda çalışmanın bulguları ilgili alanyazın ışığında tartışılmış ve çalışmanın sonuçları doğrultusunda ileriki araştırma ve uygulamalar için önerilerde bulunulmuştur.

OSB'nin çocuklar üzerindeki etkilerinin en aza indirgenmesi erken tanılama sonrasında sunulan erken özel eğitim, rehabilitasyon ve okulöncesi eğitim hizmetleri ile yakından ilişkilidir (Reichow vd., 2012). Ulusal ve uluslararası alanyazında yer alan birçok araştırma, OSB'li çocukların tanı alma süreçlerinin ebeveynlerinin, öğretmenlerinin, doktorların ya da hemşire gibi diğer tıbbi personelin, çocukların gelişimlerindeki farklılıkları gözlemlemesi ile başladığını göstermektedir. Örneğin, Karaarslan ve Karaarslan (2016), ailelerin çocuklarının gelişimlerindeki sınırlılıkları internet veya televizyondan edindikleri bilgiler yoluyla değerlendirdiklerini ve bir uzmana başvurduklarını veya çocuklarının öğretmenler, pedagoglar, psikologlar ya da çocuk doktorları tarafından fark edilip psikiyatriste yönlendirildiklerini rapor etmişlerdir. $\mathrm{Bu}$ çalışmanın bulguları, alanyazında yer alan bulgular ile uyumlu bir şekilde, OSB'li çocukların tanılanma süreçlerinin, annelerin bir önceki çocukları ya da aynı yaștaki diğer akranları ile çocuklarını karşılaştırarak çocuklarının gelişimlerindeki sınırlılıkları fark etmeleri ya da bir yakınlarının gözlemleri sonucunda çocuklardaki gelişimsel sınırlılıkları fark etmeleriyle başladığını göstermektedir. Dahası, diğer birçok ülkede olduğu gibi (Andersson vd., 2014), bazı çocuklar da normal gelişim gösteren çocukların devam ettiği kreş ya da anaokulu gibi okulöncesi eğitim kurumlarına başladıklarında, öğretmenleri tarafında fark edilerek yönlendirilmişlerdir. Erken tanılamanın OSB'li çocukların eğitimleri ve gelişimleri açısından önemi düşünüldüğünde, elde edilen bu sonuçlar çocuklara dair gözlemlerin ve bu konuda uzman olan bireylerin bilgisine başvurmanın önemini göstermektedir. Özellikle ebeveynlerin çocuklarının dil, davranış ve sosyal etkileşim becerilerine dikkat etmelerinin ve bu konuda karşılaşılan olası farklılıklar karşısında gerekli uzmanlara başvurmalarının erken müdahale ve eğitimi destekleyebileceği düşünülmektedir.

Araştırmalar, OSB'nin ilk belirtilerinin bir yaş gibi erken bir dönemde ortaya çıktığını ve gözlemlenebilir nitelikte olduğunu ancak birçok vakada tanılamanın ilk belirtilerin ortaya çıkmasından bir ya da birkaç yıl sonra yapıldığını ortaya koymaktadır (Daniels ve Mandell, 2014). Bu çalışmanın bulguları, anneleri çalışmaya katılan OSB tanısı almış 
çocukların çoğunda OSB'nin ilk belirtilerin sıfır-iki yaş aralığında ya da iki-dört yaş aralığında gözlemlendiğini ancak çocukların büyük bir çoğunluğunda tanılamanın dört yaşına yakın bir zamanda yapıldığını göstermektedir. Araştırmalar, ABD gibi OSB'nin tanılanması bağlamında öncü çalışmaların yapıldığı ülkelerde dahi OSB'den etkilenmiş çocukların büyük bir çoğunluğunun dört-beş yaş civarında ya da daha sonra tanı aldığını göstermektedir (Daniels ve Mandell, 2014, Rakap, 2017). OSB'den etkilenmiş çocuklara, gelişimin çok hızlı olduğu erken dönemlerde sunulan özel eğitim ve rehabilitasyon hizmetlerinin bu çocukların gelişim ve öğrenmeleri üzerindeki etkileri göz önünde bulundurulduğunda (McDonald vd., 2014; Reichow vd., 2013; Volkmar vd., 2014), bu çocukların daha erken yaşlarda belirlenmelerini ve tanı almalarını sağlamak amacıyla aile eğitimi ve küçük çocuklar ile erken çocukluk döneminde etkileşim kurma olasılığı olan öğretmen, hemşire ve doktor gibi uzmanların OSB ve belirtileri konusunda eğitilmelerine ve bu konuda toplumsal bilincin oluşturulmasına yönelik çalışmalar yapılmalıdır (Rakap vd., 2016).

Ulusal ve uluslararası alanyazında yer alan çalışmalar OSB'li çocuklara tanı konulması sürecinin mümkün olan en kısa sürede ve doğru bir şekilde yönetilerek yapılması gerektiğini vurgulamaktadır (Klin ve Volkmar, 2003; Rakap, 2017). Bazı araştırmalar, tanılama sürecinde, çocukların yeterliklerinin, gereksinimlerinin ve ihtiyaçlarının kapsamlı bir şekilde değerlendirilmediğini ve bu sürecin çok hızlı ve kısa bir sürede sonuçlandığını göstermektedir (Rakap, 2017; Selimoğlu vd., 2013). Oysaki, OSB tanısının, çocuğun davranışlarının sistematik olarak gözlenmesi, çocuğun ailesinden ve birincil bakım sağlayan diğer yetişkinlerden elde edilen bilgiler ve değerlendirme araçları ile yapılan değerlendirmeler sonucunda elde edilen veriler ışığında, çocuk hakkında toplanan tüm verilerin kapsamlı bir şekilde gözden geçirilmesi ve analiz edilmesi sonucunda konulması gerekmektedir (Rakap, 2017). Bu bağlamda, OSB tanısını koyan uzmanların bu özel gereksinim durumu ve karakteristik özellikler konusunda uygun düzeyde bilgiye sahip olmaları oldukça önemlidir. Araştırmalar, günümüzde, deneyimli uzmanların iki yaş öncesinde dahi OSB'nin ipuçlarını yakalayabildiğini ortaya koymaktadır (Stone vd., 1999). Örneğin, Stone vd. (1999), OSB tanısının üç yaş öncesinde güvenilir biçimde konulabileceğini, fakat tipik OSB tanısı için değerlendirmeyi yapacak kişilerin erken tanıyla ilgili deneyimli olmalarının çok kritik olduğunu belirtmektedirler. Bundan dolayı, okulöncesi yaş grubundaki çocuklarla çalışma olasılığı olan uzmanların OSB'nin erken çocukluk dönemdeki davranışsal belirtileri hakkında yeterli bilgi sahibi olmaları, çocuğun davranışlarını belli zaman aralıkları ile kontrol etmeleri ve aileler ile çocuklarının gelişimleri hakkında görüşmeler yapmaları ilk belirtilerin ortaya çıkması ile tanının konulduğu zaman arasındaki farkın kabul edilebilir zaman aralığına düşmesine olanak sunacaktır (Selimoğlu vd., 2013).

$\mathrm{Bu}$ çalışmanın bulguları, OSB tanısını almalarından itibaren tüm çocukların özel eğitim ve rehabilitasyon hizmetlerinden yararlanmaya başladıklarını göstermektedir. Çalışmaya katılan annelerin hepsi çocuklarına özel eğitim ve rehabilitasyon hizmetleri sunulduğunu belirtmesine karşın kendilerine ya da ailelerine yönelik planlanan ve sunulan bir özel eğitim ve rehabilitasyon hizmeti olmadığını belirtmişlerdir. Bronfenbrenner (1986), erken çocukluk evrelerinde sunulan müdahalelerin etkin olabilmesi için çocuğun içinde yetiştiği ailenin çocuğun gelişimi üzerindeki etkilerinin kabul gördügü ve çocuk ile birlikte anne-babalara destek ve yardım sunmayı amaçlayan erken müdahale sistemlerinin geliştirilmesi gerektiğini vurgulamaktadır. ABD gibi birçok ülkede, erken eğitim hizmetlerinin planlanması ve erken eğitim programların geliștirilmesinde bireysel aile eğitim planlarının oluşturulması yasal bir zorunluluk haline getirilmiştir (Rakap vd., 2019). Bu yasal süreç çocuğu merkezde tutup, sadece onu almak 
yerine, bir bütün olarak çocuğun içinde yaşadığı ailenin ihtiyaçlarının değerlendirilmesini ve özel eğitim ve rehabilitasyon hizmetlerinin bu temelde geliştirilmesini gerekli kılmıştır.

Ebeveynlerin çocuğa sağlanan eğitim sürecinin dışında tutulduğu çocuğu merkeze alan bakış açısının geçerliliğini kaybetmesinin en önemli sebeplerinin başında, ailelerin, çocukların gelişimi üzerinde çok önemli bir rol üstlenmelerinin fark edilmiş olması gelmektedir. Erken müdahale hizmetlerindeki bu değişimin iki önemli sebebinin olduğu söylenebilir. Bunların ilki, ailelerin işleri gibi başka sorumlulukları nedeniyle çocukları ile geçirmiş oldukları vakit sınırlı da olsa anne, baba ve kardeşler çocukların yaşamlarında çok kuvvetli bir etkiye sahiptirler. Ebeveynlerin, çocuklarıyla kendilerinin dışında hiç kimsenin gerçekleştiremeyeceği çok özel sosyal-duygusal bağları bulunmaktadır. İkincisi, ebeveynlerin çocuklarının gelişim sürecine etki etme ve onlarla iletişim kurma olasılıklarının diğer bireylere ve uzmanlara göre daha yüksek olmasıdır. Bu nedenlerden dolayı, uygulanan erken müdahale programlarının etkili olabilmesi ebeveynlere gereksinimleri ve güçlü yönleri doğrultusunda destek sunulmasıyla doğru orantılıdır. Aileler, çocukları ile ilgili yeni tutum ve becerileri geliştirmek ve uygulamak, çocuklarına nasıl yardım sağlayacaklarını ve nereden hizmet alacaklarını belirlemek ve hangi kaynakları nasıl edinebilecekleri konularında desteğe ihtiyaç duyabilirler. Erken çocukluk döneminde sunulan özel eğitim hizmetlerinin başarılı olmasında ve çocuğun gelişim sürecine olumlu yönde katkıda bulunmasında, OSB'den etkilenmiş çocukların ailelerinin eğitim süreçlerine dahil edilmesinin ve aile-uzman iş birliğinin kurulmasının önemi uzun yıllardan beri bilinmesine karşın, özellikle Türkiye'de erken çocukluk özel eğitim hizmetleri çocuk merkezli olarak yürütülmekte ve aileler genellikle bu hizmetlerin bir parçası olarak düşünülmemektedir (Özdemir, 2008). Bu bağlamda, özellikle okulöncesi dönemde sunulan özel eğitim ve rehabilitasyon hizmetlerinin aile merkezli olarak geliştirilmesine olanak sağlayacak yasal düzenlemelerin yapılması ve uygulamaya konulması gerekmektedir (Rakap, 2017). Ancak bu sayede OSB'den etkilenmiş çocukların ailelerinin uygun kaynaklara erişimi, sorunlar ile başa çlkma becerileri ve ebeveynlik yeterlilikleri kapsamlı bir şekilde desteklenebilir.

Araştırmalar, erken tanılama sonrası, iki-beş yaş aralığında çocukların ihtiyaçları doğrultunda hafta 20-40 saat yoğunluğunda sunulan erken davranışsal müdahalelerin OSB'li çocukların gelişim ve öğrenmelerini desteklemede ve OSB ile ilişkili sınırlılıklarını azaltmada etkili olduğunu göstermektedir (Reichow vd., 2012; Rakap, 2017). Bu çalışmaya katılan annelerin tamamı tanılama sonrası çocuklarının özel eğitim ve rehabilitasyon hizmetlerinden yararlanmaya başladığını ancak çocuklarına devlet tarafından ücreti karşılanarak özel eğitim ve rehabilitasyon merkezleri tarafından sunulan hizmetlerin süre ve yoğunluk olarak yetersiz olduğunu belirtmişlerdir. Birçok ailenin çocuklarına ek destek sağlamak için maddi kaynaklarının olmaması ve erken eğitimin bu çocukların gelişim ve öğrenmeleri üzerindeki etkileri göz önüne alındığında, bu çocuklara devlet tarafından ailelere ek maddi yükümlülük getirmeden sunulan özel eğitim ve rehabilitasyon hizmetlerinin süre, yoğunluk ve niteliğinin artırılması gerekmektedir.

Okulöncesi eğitim, özel gereksinimli çocuklar da dahil olmak üzere yetersizlikten etkilenmiş ve farklılıkları olan tüm çocuklar için oldukça kritik bir öneme sahiptir. Temel sınırlıkları sosyal etkileşim ve iletişim alanında olan OSB'den etkilenmiş çocukların, okulöncesi eğitim döneminde normal gelişim gösteren akranlarıyla aynı ortamlarda eğitim almaları bu alanlardaki gelişim ve öğrenmelerinin desteklenmesi için oldukça önemlidir (Yazıcı ve Akman, 2018). Bu çalışma ile ulusal ve uluslararası düzeyde yapılan birçok araştırma, OSB'den etkilenmiş çocukların büyük bir kısmının kapsayıcı eğitim 
yaklaşımına dayalı olarak gerçekleştirilen okulöncesi eğitim hizmetlerinden yararlanamadıklarını, kapsayıcı eğitim olanaklarından yararlananların ise birçok güçlükle karşılaştıklarını, çocukların büyük bir kısmının ayrıştırılmış özel eğitim ortamlarında eğitim aldıklarını ya da hiçbir eğitim hizmetinden yararlanmadıklarını göstermektedir (Ünsal ve Öksüz, 2009; Yazıcı ve Akman, 2018). Çalışma bulguları incelendiğinde, OSB'den etkilenmiş çocuğu olan ebeveynlerin çocuklarının özelliklerine uygun okulöncesi eğitim kurumu bulmakta güçlükler yaşadıkları görülmektedir. Annelerin çocuklarının gelişimsel özelliklerine uygun okul bulma bağlamında yaşadıkları güçlüklerin temelinde özel gereksinimleri olan çocuklara yönelik kapsayıcı eğitim programlarının etkili ve standart bir şekilde uygulanmıyor olması ile okul yönetimlerinin ve öğretmenlerin özel gereksinimli çocuklar ile çalışma konusunda istekli olmamaları yatmaktadır. Öğretmenlerin isteksizliğinin ise özel gereksinimli çocuklar ile çalışma konusunda sahip oldukları eğitimin sınırlı olması ve bu konuda kendilerini yetkin hissetmemeleri ile ilişkili olduğu düşünülmektedir (Bozarslan ve Batu, 2014; Rakap vd., 2018; Yazıcı ve Akman, 2018). Okulöncesi eğitim kurumlarında kapsayıcı eğitim uygulamalarının etkin ve yaygın bir şekilde kullanılması ve öğretmenler ile yöneticiler de dahil olmak üzere tüm okul personelinin özel gereksinimli çocuklar ile çalışma konusunda yetkin hale getirilmesi, bu çocuklara uygun okul bulma ve sürdürülebilir eğitim sağlanması açısından oldukça önemlidir.

Yapılan araştırmalar, özel gereksinimli çocuklara yönelik tutumlar ve sosyal kabul konusunda olumlu yönde gelişim sağlamak üzere planlanmış etkinlikler uygulanamadığında kapsayıcı eğitim uygulamalarının sınıftaki diğer çocukların özel gereksinimli akranlarını kabul düzeyleri üzerinde bir artış ortaya çıkarmadığı hatta mevcut olumsuz tutumları daha da kuvvetlendirdiğini ortaya koymaktadır (Manetti vd., 2001). OSB'nin doğasından kaynaklanan arkadaşlık ilişkisi geliştirme ile ilgili isteksiz tutum, sosyal etkileşime uygun yanıt verememe, sosyal ifadeleri çok iyi algılayamama, ilgileri ve başarıyı paylaşma konusunda eksik kalma gibi özellikler, OSB'den etkilenmiş çocukların okuldaki yaşıtlarıyla ilişkilerini olumsuz olarak etkilediği gibi çoğu zaman bu çocukların dışlanmalarına ve yalnız kalmalarına neden olur (Vickerstaff vd., 2007). Çalışmalar normal gelişim gösteren çocukların özel gereksinimli akranlarına yönelik olumsuz tavırların değiştirilmesinde, bu çocukların sosyal kabullerinin geliștirilmesinde ve normal gelişim gösteren çocukları ile özel gereksinmli akranları arasındaki etkileşimin artırılmasında bilgilendirme, canlandırma ve kendini özel gereksinimli kişilerin yerine koyarak yaşantı sağlama gibi oryantasyon etkinliklerin etkili sonuçlar sağladığını ortaya koymaktadır (Uçar, 2008). Kapsayıcı eğitim, özel gereksinimleri olan OSB'den etkilenmiş çocukların gelişim ve öğrenmelerini desteklemek amacıyla kullanılabilecek en etkin eğitim uygulamalarından birisidir; ancak, kapsayıcı eğitim, öğretmenler ve okul yöneticileri özel gereksinimli çocuklar ile çalışma konusunda istekli ve öğrenmeye açık olduklarında ve bu doğrultuda etkili bir eğitim ortamı oluşturduklarında başarılı bir şekilde uygulanabilir.

\section{Öneriler}

Elde edilen sonuçlara göre aileler OSB tanısının konulmasında sorun yaşamaktadırlar. Bu noktada OSB teşhisinin yapılabileceği standart uygulama esaslarının ve spesifik olarak bu tanı ve tedavi sürecini yürütecek kurumların yetkili makamlar tarafından açılması ve yaygınlaştırılmasının faydalı olacağı düşünülmektedir. Bu tanı ve teşhis süreci için gereken oranda ölçme araçları ve ulusal tarama işlemlerinin yapılması gereklidir. Araștırmaya katılan annelerin kendilerinin ve etrafındaki yakınlarının gözlem ve şüphelerinin erken tanı açısından önemli olduğu görülmüştür. Bu durum toplumsal 
anlamda OSB ile ilgili farkındalık çalışmalarının yaygınlaştırılmasının erken tanı sürecine katkı sunacağını göstermektedir. Anneler okul öncesi kurumlarda maliyete ve diğer çocuk, aileler ve öğretmenlerin çocuğa bakış açısıyla ilgili sorunlar yaşadıklarını bildirmişlerdir. $\mathrm{Bu}$ noktada OSB'den etkilenmiş çocukların eğitimi kadar etrafındaki bireylerin de bu paralelde bilgilendirilmesi ve sosyal destek sağlayabilecekleri şekilde yönlendirilmelerinin faydalı olacağı düşünülmektedir. Okul öncesine ait maliyetin yüksek olmasının da problem teşkil ettiği görülmektedir. $\mathrm{Bu}$ konuda da toplumun özel gereksinimli bireylerinden olan OSB'den etkilenmiş çocukların yetkili kurumlar tarafından eğitim süreçlerini sürdürecek mali desteklemenin faydalı olacağı düşünülmektedir.

$\mathrm{Bu}$ çalışma erişilebilen 14 anne ile gerçekleştirilmiştir. Bu konuda çalışacak olan araştırmacıların daha farklı örneklemler ve daha yüksek sayıda bireyle çalışmasının bu konudaki alanyazına katkı sağlayacağı düşünülmektedir. Bu araştırmada genel olarak tanı konulması ve okul öncesi eğitime ilişkin inceleme yapılmıştır. OSB'den etkilenmiş çocukların ebeveynlerinin karşılaştıkları farklı problem alanlarının da incelenmesinin hem literatürü zenginleștirmek hem de bu konuda toplumsal farkındalık yaratmak açısından önemli olacağı düşünülmektedir. OSB'den etkilenmiş çocukların bulundukları okul ve sinıflarda da eğitimcilerin dikkat etmesi gerektiği hususlar olduğu düşünülmektedir. Özellikle çocuğun sınıfında bulunan diğer çocuklar ve bu çocukların ailelerin eğitimciler tarafından doğru bilgilendirilmesinin ve etiketlemenin engellenebileceği bir ortam oluşturulmasının bu çocuklara çok önemli katkılar sunacağı düşünülmektedir. Diğer bir yandan özel gereksinimli çocukların eğitim süreci içerisinde karşılaşılabilecek süreçlerle ilişkili eğitim ve çalışmalara katılımının ve gelişimin bu çocuklara işlevsel eğitim verebilmek açısından önemli ve gerekli olduğu düşünülmektedir.

Araştırmalar, OSB'li çocukların erken çocukluk döneminden itibaren hafta da 20-40 saat arası erken yoğun davranışsal müdahale hizmetlerinden yararlandıklarında normal gelişim gösteren akranlarını yakalama potansiyellerinin olduğunu göstermektedir (Warren vd., 2011). Ancak, bu yoğunlukta bir müdahale programı aileler için oldukça maliyetlidir. Bu bağlamda, erken eğitim yoluyla OSB'li bireylerin yetişkinlikteki bakım maliyetlerinin azaltılması amacıyla, özel gereksinimli öğrencilerin rehabilitasyon merkezlerinden devletin katkısı ile ücretsiz alabileceği aylık 12 saatlik hizmetlerin, belirli gelir seviyesinin altında olup OSB'li çocuğa sahip aileler için artırılması sağlanmalıdır. Özel gereksinimli çocuklara ve ailelerine sunulan özel eğitim ve rehabilitasyon hizmetlerinin kapsam ve niteliğini artırmak ve özel gereksinimli bireylerin toplumsal hayata geçişlerini kolaylaştırmak için daha kapsamlı yasal düzenlemeler yapılmalı; bu düzenlemelerin hayata geçirilebilmesine olanak verecek altyapı çalışmaları gerçekleştirilmeli ve bu bağlamda kurumlar arası işbirliğine önem verilmelidir. Özel eğitim ve rehabilitasyon hizmeti sunan özel kurumların hizmet kalitesini artırabilmek için, Millî Eğitim Bakanlığı tarafından bu kurumların programları yeniden yapılandırılmalı, denetimler için uzmanlar yetiştirilmeli ve bu kurumlarda çalışan personelin sertifikalandırılması sağlanmalıdır (Rakap, 2017). Özetle tanı ve teşhisi destekleyecek kurum ve uygulamaların, eğitimcilerin yetiştirilmesi ve bu alandaki uzmanların arttırılmasının, özel eğitim kurumlarının ve kaynaştırma eğitimi veren okulların desteklenmesi ve denetlenmesinin ve bunlarla beraber nitelikli eğitim programlarının hazırlanması önem taşımaktadır. 


\section{Kaynakça}

Andersson, G. W., Miniscalco, C., \& Gillberg, C. (2014). Preschoolers assessed for autism: Parent and teacher experiences of the diagnostic process. Research in Developmental Disabilities, 35(12), 3392-3402. https://doi.org/10.1016/j.ridd.2014.08.027

Bıçak, N. (2009). Otizmli çocukların annelerinin yaşadıklarının belirlenmesi. [Yayımlanmamış yüksek lisans tezi]. Bolu Abant İzzet Baysal Üniversitesi.

Bozarslan, B., \& Batu, S. E. (2014). Özel anaokullarında çalışan eğiticilerin okulöncesi dönemde kaynaştırma ile ilgili görüş ve önerileri. Abant İzzet Baysal Üniversitesi Eğitim Fakültesi Dergisi, 86-108. https://doi.org/10.17240/aibuefd.2014.14.2-5000091529

Bronfenbrenner, U. (1986). Ecology of the family as a context for human development: Research perspectives. Developmental Psychology, 22(6), 723-742. ttps://doi.org/10.1037/0012-1649.22.6.723

Büyüköztürk, Ş., Kılıç, Ç. E., Akgün, E., Karadeniz, Ş., \& Demirel. F. (2015). Bilimsel araştırma yöntemleri. Pegem Akademi.

Centers for Disease Control and Prevention. (2020). Prevalence of autism spectrum disorder among children aged 8 years autism and developmental disabilities monitoring network, 11 sites, United States, 2016. MMWR Surveillance Summaries, 69(4), 1-12. https://doi.org/10.15585/mmwr.ss6904a1

Creswell, J. W. (1998). Qualitative research and research design: Choosing among five traditions. Thousand Oaks.

Daniels, A. M., \& Mandell, D. S. (2014). Explaining differences in age at autism spectrum disorder diagnosis: A critical review. Autism, 18(5), 583-597. https://doi.org/10.1177/1362361313480277

Güleç-Aslan, Y., Cihan, H., \& Altın, D. (2014). Otizm spektrum bozukluğu tanılı çocuğa sahip annelerin deneyimleri. Elektronik Sosyal Bilimler Dergisi, 13(50), 96-111. https://doi.org/10.17755/esosder.41128

Karaaslan, Ö., \& Karaaslan, D. (2016). Otizmli çocukların tıbbi tanılama sürecinde yer alan uzman doktorların tanılamaya ilişkin görüşlerinin incelenmesi. Trakya University Journal of Social Science, 18(2), 271-293

Klin, A., \& Volkmar, F. R. (2003). Asperger syndrome: Diagnosis and external validity. Child and Adolescent Psychiatric Clinics of North America, 12(1), 1-13. https://doi.org/10.1016/S1056-4993(02)00052-4

Leblanc, L., Richardson, W., \& Burns, K. A. (2009). Autism spectrum disorder and the inclusive classroom: Effective training to enhance knowledge of ASD and evidencebased practices. Teacher Education and Special Education, 32(2), 166-179. https://doi.org/10.1177/0741932507334279

MacDonald, R., Parry-Cruwys, D., Dupere, S., \& Ahearn, W. (2014). Assessing progress and outcome of early intensive behavioral intervention for toddlers with autism. Research in Developmental Disabilities, 35(12), 3632-3644. https://doi.org/10.1016/j.ridd.2014.08.036 
Manetti, M., Schneider, B. H., \& Siperstein, G. (2001). Social acceptance of children with mental retardation: Testing the contact hypothesis with an Italian sample. International Journal of Behavioral Development, 25(3), 279-286. https://doi.org/10.1080/01650250042000249

Özdemir, S. (2008). Family centered early intervention services. E-Journal of New World Sciences Academy, 3(2), 321-334.

Rakap, S. (Ed.). (2017). Türkiye'de otizm spektrum bozukluğu ve özel eğitim. Tohum Autism Foundation.

Rakap, S., Balikci, S., \& Kalkan, S. (2018). Teachers' knowledge about autism spectrum disorder: The case of Turkey. Turkish Journal of Education, 7(4), 169-185. https://doi.org/10.19128/turje.388398

Rakap, S., Balikci, S., Parlak-Rakap, A., \& Kalkan, S. (2016). An analysis of Turkish preservice teachers' knowledge of autism spectrum disorder: Implications for teacher preparation programs. SAGE Open, 6(3), 1-11. https://doi.org/10.1177/2158244016668853

Rakap, S., Yucesoy-Ozkan, S., \& Kalkan, S. (2019). How complete are individualized education programmes developed for students with disabilities served in inclusive classroom settings?. European Journal of Special Needs Education, 34(5), 663-677. https://doi.org/10.1080/08856257.2019.1580840

Reichow, B., Barton, E. E., Boyd, B. A., \& Hume, K. (2012). Early intensive behavioral intervention for (EIBI) young children with autism spectrum disorders (ASD). Cochrane Database of Systematic Reviews, 2012(10), 1-46. https://doi.org/10.1002/14651858.CD009260.pub2

Selimoğlu, Ö. G., Özdemir, S., Töret, G., \& Özkubat, U. (2013). Otizmli çocuğa sahip ebeveynlerin otizm tanılama sürecinde ve tanı sonrasında yaşadıkları deneyimlerine ilişkin görüşlerinin incelenmesi. International Journal of Early Childhood Special Education, 5(2), 129-161. https://doi.org/10.20489/intjecse.107930

Stone, W. L., Lee, E. B., Ashford, L., Brissie, J., Hepburn, S. L., Coonrod, E. E., \& Weiss, B. H. (1999). Can autism be diagnosed accurately in children under 3 years? Journal of Child Psychology and Psychiatry, 40(2), 219-226. https://doi.org/10.1111/1469$\underline{7610.00435}$

Töret, G., Özdemir, S., \& Özkubat, U. (2015). Ciddi düzeyde otizm spektrum bozukluğu olan çocuklar ile annelerinin ebeveyn-çocuk etkileşimlerinin ebeveyn ve çocuk davranışları açısından incelenmesi. Ankara Üniversitesi Eğitim Bilimleri Fakültesi Özel Egitim Dergisi, 16(1), 1-22. https://doi.org/10.1501/Ozlegt 0000000217

Uçar C. (2008). Farklı gelişenleri kabul edici tutum geliştirme programının normal gelişen öğrenci tutumlarının gelişimine etkisi. [Yayımlanmamış yüksek lisans tezi]. Marmara Üniversitesi.

Ünsal, E., \& Öksüz, Ç. (2018). Otizm spektrum bozukluğu olan çocuklarda kaynaştırma eğitiminin uzman ve ebeveyn bakış açısı ile incelenmesi. Ergoterapi ve Rehabilitasyon Dergisi, 6(1), 31-36. https://doi.org/10.30720/ered.417699

Üstüner-Top, F. (2009). Otistik çocuğa sahip ailelerin yaşadıkları sorunlar ile ruhsal durumlarının değerlendirilmesi: Niteliksel araştırma. Çocuk Dergisi, 9(1), 34-42. 
Vickerstaff, S., Heriot, S., Wong, M., Lopes, A., \& Dossetor, D. (2007). Intellectual ability, self-perceived social competence, and depressive symptomatology in children with high-functioning autistic spectrum disorders. Journal of Autism and Developmental Disorders, 37(9), 1647-1664. https://doi.org/10.1007/s10803-006-0292-X

Volkmar, F. R., Paul, R., Rogers, S. J., \& Pelphrey, K. A. (2014). Handbook of autism and pervasive developmental disorders (4th ed.). John Wiley and Sons. https://doi.org/10.1002/9781118911389

Warren, Z., McPheeters, M. L., Sathe, N., Foss-Feig, J. H., Glasser, A., \& VeenstraVanderWeele, J. (2011). A systematic review of early intensive intervention for autism spectrum disorders. Pediatrics, 127(5), 1303-1311. https://doi.org/10.1542/peds.2011-0426

Yazıcı, D. N., \& Akman, B. (2018). Okul öncesi öğretmenlerinin otizmli çocukların kaynaştırılması hakkındaki düşüncelerinin incelenmesi. Ankara Üniversitesi Eğitim Bilimleri Fakültesi Özel Eğitim Dergisi, 19(1), 105-128. https://doi.org/10.21565/ozelegitimdergisi.284253

\section{Extended Summary}

\section{Examining Experience of Mothers of Children with Autism about Preschool Services}

\section{Introduction}

Autism Spectrum Disorder (ASD) is a neurodevelopmental disorder that adversely affects the social interaction and communication skills of individuals and causes limited interest and repetitive behavior (Leblanc et al., 2009). Although there are no conclusive research findings about the causes of ASD, studies conducted for more than thirty years show that the most effective results in the treatment of ASD are obtained by diagnosing the child in the early period and starting special education and intensive behavioral therapy as soon as possible (Reichow et al., 2012; Volkmar et al., 2014). Considering the effects and benefits of early intervention on these children, it is very important that children with ASD are diagnosed as early as possible using a comprehensive evaluation process and receive early intervention services immediately (Rakap, 2017). In this context, there are many problems faced by children with ASD and their families in the period from noticing the first symptoms of ASD to diagnosis and accessing early education and preschool education programs after diagnosis. The purpose of this study was to investigate experiences of mothers of children with ASD during diagnosis and early education process. Following research questions were addressed in the present study:

1. What are the experiences of the mothers with children with ASD in the diagnosis process?

2. What are the experiences of the mothers of children with ASD while enrolling their children in preschool education institutions?

3. What are the experiences of the mothers of children with ASD during preschool education? 
4. What are the experiences of mothers of children with ASD with the administrators and teachers working in the preschools and typically developing children and their families who receive education in these institutions?

5. What are the opinions of the mothers of children with about the quality of educational services they received in preschool period?

\section{Method}

In this study, the case study method, one of qualitative research designs was used in order to examine the experiences of mothers of children with ASD during diagnosis and early education process. Fourteen mothers whose children were diagnosed with ASD and living in the provinces of Istanbul were included in this study. Three criteria were used in the selection of the mothers to participate in the study: (1) their child being diagnosed with ASD, (2) their child being between the ages of 4-7, and (3) their willingness to participate in the study. A Demographic Information Form and Semi-Structured Interview Form developed by the researchers were used to collect data in the study. Five open-ended questions were included in the Interview Form in order to determine the experiences of mothers with children diagnosed with ASD in the diagnosis and preschool education period. All of the interviews were conducted with the participants individually by the first researcher and were recorded with a tape recorder, with the permission of the participating mothers. Interviews with the mother lasted 32-40 minutes (mean $=36$ minutes). At the beginning of each interview, the purpose of the study and how the information obtained will be used in line with the confidentiality principles and rights as a participant was explained to the participants again and the consent forms were signed. Descriptive and content analysis methods were used to analyze the qualitative data collected in the study. Before starting the data analysis phase, four of the interview recordings selected randomly were listened to by a second observer for reliability and the accuracy of the written transcripts was checked. The interobserver reliability was $100 \%$.

\section{Findings}

Findings revealed that mothers started diagnosis process due to their own doubts, with the guidance of their relatives or their children's teachers and that diagnosis process was generally completed in 2-4-year range. Findings also revealed all children started to receive special education and rehabilitation services after diagnosis, but the quality of these services varied; while $5(35.7 \%)$ of the mothers evaluated the quality of services they received as insufficient, 6 (42.9\%) stated that services could be improved, and 4 $(21.4 \%)$ stated that it was sufficient. Moreover, children with autism faced many challenges in accessing preschool education. Participating mothers stated that the most important difficulty they faced in finding suitable preschool and classes for their children with ASD was that preschool institutions did not want to enroll children with disabilities. Participants stated that the negative view of teachers and school administrators towards children with ASD and their lack of knowledge about ASD are among the most common problems they experienced. Mothers also reported that they experienced some difficulties while enrolling their children to preschool. One of the mothers stated that the schools refused them or that the administrators wanted to see the child before enrollment. Another mother stated that her child was not accepted to the class by the teacher due to his active nature and therefore he was not enrolled in the school. Mothers in the study also reported that their children faced some difficulties when placed in preschool 
classroom. For example, their friends treated their children as if they were babies rather than their peers, or that their children were kept separate from their peers in other areas.

\section{Discussion}

Studies in the national and international literature show that the diagnosis process for children with ASD starts with the observation of the differences in children's development by their parents, teachers, doctors, or other medical personnel. In line with the findings in the literature, findings of this study showed that the process of diagnosing started when mothers noticed the limitations in their children's development by comparing their children with their previous children or other peers of the same age, or when a relative noticed developmental limitations in their children. Studies reveal that the first symptoms of ASD appear as early as one year of age but in many cases the diagnosis is made one or a few years after the first symptoms appear (Daniels and Mandell, 2014). Findings of this study showed that the first symptoms of ASD were observed in the age range of zero to two years or between the ages of two and four, but the diagnosis was made at the age of four years in most children.

The findings also showed that all children started to benefit from special education and rehabilitation services since the diagnosis of ASD. Although all of the mothers participating in the study stated that special education and rehabilitation services were provided to their children, they stated that there was no special education and rehabilitation service planned and offered for themselves or their families.

Although the importance of including families of children with ASD in education processes and establishing family-expert collaboration for the success of special education services offered in early childhood has been known for many years, early childhood special education services in Turkey are carried out as child-centered and families are not generally considered as part of these services (Özdemir, 2008). In this context, legal arrangements that will enable the development of special education and rehabilitation services, especially in the preschool period, on a family-centered basis, should be made and put into practice (Rakap, 2017).

Studies show that early behavioral interventions, presented 20-40 hours a week between the ages of two and five are effective in supporting the development and learning of children with ASD and reducing their limitations associated with ASD (Reichow et al., 2012; Rakap, 2017). All of the mothers participating in this study stated that the services provided by the special education and rehabilitation centers to their children at the cost of the state were insufficient in terms of duration and intensity.

\section{Yazar(lar)ın Beyanı}

Araştırmacıların katkı oranı beyanı: Araştırmanın verileri birinci yazar tarafından toplanmış ve ikinci yazarın katkısı ile analiz edilmiştir. Her iki yazar, makalenin yazım aşamasına katkıda bulunmuştur. Araştırmacılar çalışmaya eşit oranda katkı sağlamışlardır.

Etik Kurul Kararı: Okan Üniversitesi Etik Kurulu'ndan 04.07.2018 tarih ve 29 sayılı Etik Kurulu Onayı alınmıștır.

Çatışma beyanı: Araştırmada yazarlar arasında ya da diğer kişi/kurum/kuruluşlarla herhangi bir çıkar çatışması bulunmamaktadır.

Destek ve teşekkür: $\mathrm{Bu}$ araştırma için herhangi bir kurumdan finansal destek alınmamıştır. 